\section{第31群 喉頭一症例（2）}

座長 三宅 浩郷（東海大耳鼻科）

113）喉頭アミロイドーシスの組織学的観察

永田博史, 吉原俊雄, 野本 実, 石毛俊行 神田 敬，金子敏郎（千大耳鼻科）

喉頭アミロイドーシスは, 喉頭疾患の中でも稀なも のであるが，その症例報告は，決して少なくない。し かし，その電顕的観察についての報告は，非常に少な いのが現状である。今回，我々は，54歳女性の，限局 性の喉頭アミロイドーシス症例を経験したので，その 光顕および電顕所見について報告した。

患者は, 約 10 年来の断続的嗄声を主訴に，当科を受 診した。診察所見では，喉頭蓋から両側被裂部，仮声 带にかけて，結節状の黄色の膨隆を認めたが，喉頭蓋 から組織を採取し検索に用いた。なお，術前の検査に おいて，血液，尿，心電図等に異常を認めず，術後の 直腸生検でも,アミロイドの沈着は認められなかった。

組織学的には，コンゴ赤染色で，上皮直下より，均 一無構造のびまん性アミロイド沈着が認められ, 細胞 成分は非常に乏しかったが，血管は此較的よく保たれ ていた。同標本は，偏光顕微鏡下に，緑色複屈折性を 示したが，この染色性は，過マンガン酸カリによる前 処理に抵抗性であり,アミロイド蛋白の種類が, AA で はないということが示された。また，PAP法による検 索(山口大病理, 横田先生の御好意による)では抗 AA, AL, pre-albumin に対しては陰性であり，抗 P-componentに対してしか陽性を示さなかった。電顕では定 型的なアミロイド細線維が確認されたが，細胞成分で は,アミロイドを取り囲むように伸展した細胞の他に， 線維芽細胞, 大食細胞, 単球, 形質細胞などが見られ, いずれも，アミロイドと細胞膜の直接接触は認められ なかった。また，血管は，内皮細胞，基底膜共によく 保たれていたが，周囲を，線維芽細胞が層状に取り囲 む像が多く観察された。

質問：三宅治郷（東海大耳鼻科）

発表証例は，喉頭に限局した症例か治療法として何 を選択したか。

応答：永田博史（千大耳鼻科）

呼吸困難がなかったので，特に治療を行なっていな い。プローべを採取するにとどめた。

質問：鈴木 徹 (今治市, 開業耳鼻科)

アミロイド蛋白同定のための標本の固定法は。

応答：永田博史

ホルマリン（10\%）を用いた。約半日であったが， 今回抗 AL 抗体に反応が陰性だったのは, 抗原性失活 によるものか, 属する subgroup が異なるためなのか は分らない。

114）喉頭気管気管支アミロイドーシスの 1 症例 浦野正美，田中久夫，佐藤弥生，野々村直文 中野雄一 (新大耳鼻科)

富樫孝一(新潟ガンセンター耳鼻科)

気道のアミロイドーシスはまれな疾患であるが，そ のほとんどは喉頭に発生し，気管気管支にまで及んで いるものは少ない。今回われわれは，喉頭気管気管支 アミロイドーシスの 1 症例を経験したので報告する。

症例は 30 歳, 男性。昭和 54 年 5 月より嗄声が持続し,
近医にて保存的療法を受けていたが軽快しなかった。 昭和 58 年10月より労作時の呼吸困難が出現するように なったため，昭和 59 年 1 月 24 日当科を受診した。初診 時, 仮声帯がびまん性に腫脹し, 粘膜下腫锡を思わせ る所見であった。喉頭断層撮影では, 喉頭から気管に かけての狭窄が認められた。入院後，気管切開術を施 行し, 喉頭気管の直達鏡検査, 喉頭および気管の生検 を行った。病理組織検査では, 上皮下にエオジン好性 の無構造均一物質の沈着が認められた。この物質は,

Congo redによりオレンジ色に染色され, 偏光顕微鏡 で緑色偏光を呈したため,アミロイドと判明した。CT 検査扔よび気管支鏡検査により，気管支にまでアミロ イドが沈着しているのが確認された。全身の検索の結 果, 他㵴器へのアミロイドの沈着はなく, また続発生 アミロイドーシスを起こすような疾病もなかったこと から原発性喉頭気管気管支アミロイドーシスと診断し た。喉頭, 気管, 気管支と広範にアミロイドの沈着が みられたため, 外科的切除は困難と判断し, 気管力二 ユーレを挿入したまま経過観察中である。

本邦での気道アミロイドーシスの報告は1960年以降 54 例があるが，その $90 \%$ は喉頭に限局している。本症 例のように喉頭から気管支にまで広く及んだ症例はい まだ報告がない。本邦での54例について考察を加える と共に下気道にアミロイドが沈着した場合の問題点を 検討した。

追加, 質問 松永 亨 (阪大耳鼻科)

公害による喘息とされ，嗄声を訴えたのち喉頭・気 管・気管支アミロイドーシスと診断された 1 例を追加 する。これらの患者で全身の他部位へのアミロイド沈 着の有無は。

応答：浦野正美（新大耳鼻科）

心，肺，腎の機能検査及び画像検査，直腸生検，骨 䯣穿刺の検索の結果, 他臓器へのアミロイド沈着はな かった。全身性アミロイドーシスと限局性アミロイド ーシスの合併は少ない。

\section{5）喉頭肉芽腫症例}

宮田英雄，藤原宏寿，五島桂子 (岐大耳鼻科)

頻度が少なく，再発しやすいとされている非特異性 喉頭肉芽腫症例を経験したので報告した。

$<$ 症例 $>53$ 歳主婦。既往症：昭和 24 年肺炎, 39年子 宮外妊娠にて手術。音声酪使, 喫煙, 飲酒なし。現病 症：昭和 57 年 1 月感昌に罹患後嗄声をきたし回復しな いので, 同年 6 月近医を受診し慢性喉頭炎として保存 的治療をうけたが軽快せず。 58 年 6 月他医で組織検査 をうけ結核性も疑われた。しかし, 胸部X線異常なく, 喀痰培養で結核菌陰性で治療うけず。近医を再受診し 59 年12月まで治療をうけたが，嗄声增強，階段の上下 で息苦しくなり 60 年 1 月 23 日当科入院。入院時喉頭所 見は喉頭蓋変形あり。前連合から左声帯, 仮声帯にか けて肉芽増殖し左声帯は認嫨く声門は狭かった。発 声持続時間は 3 回平均 17.3 秒。鼻鏡検査で粘膿性鼻汁 あり。赤沈 1 時間值 $38 \mathrm{~mm}$ 。ツ反応 $30 \times 20 / 55 \times 38$ $\mathrm{mm}_{\mathrm{o}}$ 胸部 $\mathrm{X}$ 線, 喀痰培養異常なし。梅毒血清反応陰性。 喉頭微細手術で肉芽を紺除し, 組織検査を行った。慢 性肉芽腫性喉頭炎であった。術後，抗生剂とリンデロ 
ンの喉頭ネブライザー, 酵素剤内服, 鼻処置, 声の制 限を行った。発声持続時間26.3秒と改善し，2月12日 退院。現在, 術後 9 力月で外来にて上記保存的治療を 続け経過観察中で, 喉頭の肉芽増殖は強く認めていな w。

〈考察〉本症は20歳以下にみらず，男性，片側に多 い。発生部位は声帯後部に好発すると報告されている。 本例は53歳女性で, 前連合から左声帯, 仮声帯に発生 し, 喉頭蓋の変形を認めた。成因は，市村らは何らか の刺激で喉頭粘膜に微細な外傷が加えられ, そこから 微生物が侵入し炎症をおこし肉芽腫が形成されるとし ている。本例は感昌に罹患したり，鼻漏のために咳払 いをしたのが刺激になり，発症したのかも知れない。 治療は沈黙, 発声法の再教育, 吸入, 咳払いの禁止, 上気道感染の治療などとある程度の大きさに達した場 合は外科的治療が必要とされている。

質問：進 武幹（佐賀医大耳鼻科）

喉頭肉芽腫の病変は声帯披裂軟骨突起部に多いが, この症例とは少し原因が違うのではないか。

応答：宮田英雄（岐大耳鼻科）

現在, 赤沈, ツ反応以外の臨床化学検査, 胸部 X線, 喀疾培養に異常なく, 病理組織検査で慢性肉芽腫性喉 頭炎であり, Kleinsasser の分類の術後性, 插管性, 接 触性にもあてはまらず原因不明として観察している。

\section{6）挿管後の喉頭肉芽腫の成因に関する研究 \\ 一披裂軟骨声帯突起部の損傷一}

織田正道，渡辺 宏，松尾浩一，進 武幹 (佐賀医大耳鼻科)

気管内挿管後の喉頭肉芽腫は，そのほとんどが披裂 軟骨声帯突起部より発生するといわれている。われわ れは挿管後の喉頭肉芽腫の成因を追究する目的で，挿 管後の剖検屍体より得られたヒト喉頭35例：左右半截 喉頭56側について，特に披裂軟骨声帯突起部の損傷の 程度を組織学的に Grade I 〜 IVに分類することによ って明確にし，さらにこの損傷に影響をおよぼすと考 えられる臨床的な諸因子について具体的に検討し, 次 の結果を得たので報告する。

1. 披裂軟骨声帯突起部の損傷は, 上皮欠損, 粘膜固 有層の変性, うつ血, 細胞性反応, 粘膜固有層の壊死 あるいは欠損，さらには披裂軟骨の露出と一連の変化 を認める。これらの損傷は，壊死性変化が主体をなし ており，挿管チューブの物理的圧迫によるものと考え られる。

2. 損傷の程度は, 插管時間に比例し高度となってい る。

3. 損傷の程度に左右差は認められない。

4. 挿管時間24時間以上の例では, 損傷の程度は女性 が男性に比べ高度となる傾向がみられる。また，插管 チューブサイズと声带長を比較すれば女性の方が男性 より太めのチューブが使用される。

5. 損傷の程度と臨床検査成績 (血清総蛋白量, 血清 アルブミン值，へマトクリット值）との間には関係は みられない。

6. 挿管時間 12 時間以上の例では, 損傷の程度は respirator 未使用例が使用例に比べ高度となる傾向がみ られる。
質問：三宅浩郷（東海大耳鼻科）

レスピレーター着装群が損傷が少ないのは麻酔が深 いためか，意識がないためか。

応答：織田正道（佐賀医大耳鼻科）

Respirator 未使用例では自発呼吸があり，声門の開 閉運動, 嚥下運動のためチューブによる擦過の機会が 多くなるため損傷が増大すると考えられる。

\section{第32群 下咽頭・食道一悪性腫瘍（1）}

座長 佐藤 武男 (大阪成人病センター耳鼻科)

117）下咽頭癌の喉頭内浸潤 栗田茂二朗，平野 実，田中久志 (久大耳鼻科)

久留米大学耳鼻咽喉科において喉摘を行なった下咽 頭癌19例について, 大切片連続段階切片を作製し, 下 咽頭癌の喉頭内浸潤について検討を加えた。対象は PS 15例, PC 2 例, PW 2 例である。

喉頭の軟骨浸潤のみられたものは，19例中 7 例 $(37$ \%) で，内喉頭筋浸潤があったものは，9例 (47\%)， 仮声帯浸潤は10例（53\%）であった。

下喉頭癌の喉頭内浸潤は，(1)仮声带レベルでは甲状 軟骨の内側 paraglottic space に沿って浸潤する, (2)声 帯レベルでは, 梨状陷凹外側壁のものは paraglottic spaceに浸潤し, 梨状陥凹内側壁のものは, 披裂軟骨筋 突起に沿って浸潤する，(3)甲状軟骨は板の最後端より 破壊されやすい。

部位別， T別に喉頭内浸潤の程度をみると(1)PS $\mathrm{T}_{2}$ では喉頭内浸潤の頻度, とくに声帯筋浸潤の頻度は少 なく，あってもごくわずかである。

(2)PS T $\mathrm{T}_{3}$ でも声帯筋浸潤のないものがある。仮声帯 浸潤はあると考えた方がよい。

(3)PS T 4 では, 軟骨浸潤, 声帯筋浸潤ともにある。

(4)PC, PW でも癌が PS に及んでいなければ, 声帯 レベルの浸潤はない。

(5)PC $\mathrm{T}_{3}$ でも声帯筋浸潤のないものがある。

質問：小宮山荘太郎 (九大耳鼻科)

下咽腫の場合，喉頭部切は可能か。

応答：栗田茂二朗 (久大耳鼻科)

下咽頭癌の喉頭保存例については, 現在経過観察中 である。

応答：武宮三三（千葉がんセンタ一頭頸科）

例えばPearsonによると, PSの症例を選んで extended hemilaryngectomyをおこなった29例の成績 は, total laryngectomyのそれに劣らないという。

追加，質問：武宮三三

甲状舌骨膜から出るリンパ管に沿う浸潤はなかった か。

低目に在る PCでは， $\mathrm{T}_{2}$ であっても輪状軟骨下端の 軟部組織を経て内腔の粘膜に浸潤する症例がある。

応答：栗田茂二朗

甲状舌骨膜よりのリンパ管内には，PCでは癌はみ られなかった。

質問：谷 光毅（神大耳鼻科）

軟骨膜あるいは筋膜へ腫瘍が接触する場合の取り扱 いについて。

応答：栗田茂二朗 
軟骨については，軟骨内に入っているものを浸潤と した。筋は筋膜まで浸潤していれば浸潤としたが，内 喉頭筋の筋膜はそれほどはっきりしない。

118）発表中止

119）梨状陥凹癌の臨床病理組織学的研究（第 4 報） 一下咽頭食道造影検査所見と組織学的進展度との 関係一

谷 光毅, 天津睦郎（神大耳鼻科）

梨状陷凹癌の術前非照射例20例の摘出標本を用い て, 水平断, $4 \mathrm{~mm}$ 間隔で連続的に切り出し, 段階的大 切片 $\mathrm{H}-\mathrm{E}$ 染色標本を作製した。これらの標本をもと に, 術前の下咽頭食道造影所見と癌の進展度との関係 につき検討した。

1）造影法別にみた腫瘍の描出率は, 正面粘膜レリ 一フ像で100\%, 正面充盈像で77\%であった。側面像で は解剖学的位置関係で梨状陥凹がバリウム内に埋没 し，描出率は $12 \%$ と低かった。

2 ）梨状陥凹外側壁については，造影所見から腫瘍 の外方への進展度を推察する事がある程度可能であ り，特に壁が不整に描出される場合，腫瘍が甲状軟骨 の外方へ進展している可能性が大きい。一方, 内側壁 については, 組織学的に腫瘍浸潤のない症例でも, 全 例で異常像を認めた。従って内方の喉頭への深達を造 影所見から推察することは，きわめて困難である。

3 ）粘膜レリーフ像で梨状陥凹先端部が不整に描出 された症例（6例）や, 先端部が健側に較べて浅いも の, すなわち梨状陷凹の内, 外側壁が上方では描出さ れるが，先端部は陰影が欠損している症例（6例）で は, 組織学的に先端部に腫瘍浸潤を認める場合が多い $(10 / 12=83 \%)$ 。一方，患側梨状陥凹が全く描出されな い症例（7 例）では約半数（3 例）で先端部は組織学 的に正常であった。陰影全欠損例では，先端部の状況 は推察が困難である。

4) 組織学的に, 食道入口部に腫場の深達を認めた 症例（2 例）では，側面の充盈像および粘膜レリーフ 像で, 入口部に深達を思わせる壁の不整像を認めた。 食道入口部では, 粘膜面での変化をバリウム造影で捕 える事が容易であり，腫瘍の下方進展の推察に極めて 有用といえる。頸部食道への進展がなく，下咽頭後壁 への進展がなければ, 多くの梨状陥凹癌は拡大喉頭全 摘出術で摘出が可能であるため, 食道入口部の状況を バリウム造影で術前に知ることは重要な事と考えられ る。

質問：久保田元（浜松医大放射線科）

Valsalva 法を用い梨状窩下端の情報は増えないも のか。

応答：谷 光毅（神大耳鼻科）

現在は，造影について特別な工夫をしておらず，充 盈像と粘膜レリーフ像で診断を行っている。

質問：桜井一生（藤田学園耳鼻科）

上方進展の程度をみるにはどのような方法が良いと 思われるか。

応答：谷 光毅

上方進展については, 造影所見からは推察が困難で, 視診, 頸部レントゲン写真, CT などで粘膜下の病変を 推察することになる。摘出標本での上方での粘膜下進

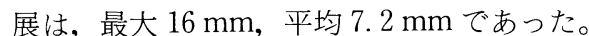

質問：内田正興（癌研頭頸科）

$\mathrm{PC}$ のX線診断の価値について。

応答：谷 光毅

梨状陥凹癌の輪状後部への進展については, 斜位像, 側面像で, 推察が可能な症例もある。輪状後部癌の造 影所見については，今後検討したい。

\section{0）下咽頭癌患者死亡例の臨床的検討}

鶴田至宏，佐藤武男，宮原 裕，吉野邦俊 馬谷克則（大阪成人病センター耳鼻科）

1979年 1 月より 1983年12月までに当センターで加療 した下咽頭癌一次症例88例のうち，1985年 6 月までに 死亡した症例について臨床的検討を加えた。一次症例 は梨状窩61例, 輪状軟骨後部14例, 後壁 9 例で, 男女 比 $3 ： 1$, 平均年齢 62.9 歳であった。病期分類は I 期 2 例 $(2.4 \%)$, II 期 8 例 $(9.5 \%)$, III期 13 例 $(15.5 \%)$, IV期61例 $(72.6 \%)$ であった。このうち54例 (64.3\%) が死亡し, 原病死 48 例, 他病死 3 例（脳血管障害 2 , 肺炎 1 ), 他癌死 3 例 (胃癌, 肝癌, 直腸癌各 1 ) であ つた。原病死症例の病期分類別にみた死亡数 (死亡率) は, I 期 1 例 (50\%), II 期 4 例 (50\%), III期 6 例 (46.2 $\%), I V$ 期 43 例 $(70.5 \%)$ であり，すくなくともIII期ま での早期発見が望まれた。また TN 分類では T因子よ りも $\mathrm{N}$ 因子の方が予後を決定する因子であり, $\mathrm{N}_{0}, \mathrm{~N}_{1}$ の死亡率は約 $40 \%$ であるが, $\mathrm{N}_{2}, \mathrm{~N}_{3}$ では約 $80 \%$ にな った。原病死の first failure の部位は原発部位15例, 頸 部リンパ節転移21例 (うち 4 例は $\mathrm{M}_{1}$ ), 遠隔転移 12 例で あった。局所再発では食道側再発が半数を占め，頸部 リンパ節転移では上頸部，気管孔周囲が死因となるも のが多かった。したがって，癌の上方，深部浸潤を配 慮した広範な咽頭切除と甲状腺半切を加えた気管周囲 リンパ節の郭清が必要と思われた。遠隔転移は20部位 で肺 10 , 胃 6 , 肝 3 , 脳 1 であり，このため我々は化 学療法を加えた集学療法を導入した。化学療法の効果 が最大限に期待できるように術前，照射前に施行し， これまでの奏効率は原発部位に関して 1 クール 69.2 \%， 2 クール $90 \%$ ，また頸部リンパ節転移に関して 1 クール $50 \% ， 2$ クール 77.8\%であった。経過観察が短 いため遠隔転移については未検討であるが，少なくと も術前照射と比べて奏効率に遜色はなく，また局所の 血行が障害されないため, 手術操作が容易となり, 重 篤な術後合併症は認めず, 良好な成績を得ている。

質問：内田正興（癌研頭頸科）

(1)全症例に対する手術例の頻度について。

(2)重複癌の頻度について。

応答：鶴田至宏（大阪成人病センター耳鼻科）

(1)手術施行率は全例（84例）では約 $90 \%$ である。

(2)重複癌は 7 例に認めたが他癌死となったのは 3 例 であった。

\footnotetext{
第33群 下咽頭・食道一悪性腫瘍（2）

座長 竹山 勇 (聖マリ医大耳鼻科)

121）食道癌術後嗄声発生症例の検討 門馬公経, 竹岡秀生, 田島芳雄 (獨協医大第二外科) 越井健司，平林秀樹，日野原正
} 
(獨協医大気食科)

頸部食道癌を除いた原発性食道癌で一期的に胸部食 道全摘・頸部食道胃吻合術を施行した40例を対象とし て, 術後の嗄声発生状況について検討した。なお，切 除と再建を二期的に分割した症例や手術死亡例，術後 1 か月以上にわたって respirator 管理を必要とした 症例などは除外した。嗄声の判定は, 術後 $1 \sim 3$ か月 間に自覚的，他覚的に臨床的に発声困難や声変りを認 めたものを嗄声とした。術後嗄声は40例中 22 例 $(55.0$ \%)に発生し，半数以上を占めた。このうち，声帯所 見の得られた 14 例では，10例が左反回神経麻痺，4例 が両側反回神経麻痺と診断され，右反回神経麻痺と診 断された症例はなかった。嗄声の程度は軽度のものが 大部分で，1〜2 か月でほぼ症状の改善がみられてい るが，誤嬹を伴うものが 4 例あった。また，嗄声高度 例 4 例には声帯内シリコン注入術が行われ, 術後は良 好であった。食道癌部位別に嗄声発生頻度をみると， Iu $100 \%$, Im $46 \%$, Ei $67 \%$, Ea $50 \%$ と, Iu の全例に 発生をみているが, 胸部下部食道癌でも高率であった。 術前照射との関係では, 術前照射施行例22例中13例 (59 \%) に嗄声が発生し，非施行例の50\%に比べやや高率 であった。手術術式では，われわれの標準術式である 右開胸開腹・胸骨後経路食道胃吻合術を行った 33 例中 17例（55\%）に発生し，全症例の発生率と同率であっ たが，食道抜去術を行った 4 例では 3 例（75\%）に嗄 声発生がみられ, 盲目的上縦隔操作が原因と推測され た。その他, 気管内挿入時間, 術後肺合併症との関係 では，嗄声発生にほとんど差はなかった。

以上の結果より, 頸部, 上緹隔の手術操作が術後嗄 声発生の最も大きな要因と考えられた。

質問：田中 隆（日大第三外科）

(1)嗄声は頸部郭清の程度, 上縦隔の郭清と関係ない 加。

(2)Blunt dissectionの症例は胸部上部食道癌などで 盲目的な上縦隔の郭清のためでないか。

応答：門馬公経（獨協医大第二外科）

(1)頸部郭清は十分に行っていない。上縦隔郭清は出 来るだけ右側まで行っている。

(2)Blunt dissection の症例は Im 症例が 1 例の他は 下部食道癌であった。

質問：堤内邦彦（都立駒込病院耳鼻科）

大半の嗄声軽快例のうち, 反回神経麻痺が軽快した ものは，どれ位か。

応答：門馬公経

術後 $2 \sim 3$ か月以内に嗄声の改善した症例は，挿管 性声帯麻痺も考えられるが，挿管時間と嗄声発生率と の相関はなかつた。

質問：村上 泰（慶大耳鼻科）

一側へシリコン注入をした後で，反対側麻痺をきた して危険となった経験がある。根治度のわるい手術後 では，安易にシリコン注入するのはよくないと思うが どうか。

\section{応答：平林秀樹（獨協医大気食科）}

声带シリコン注入時期の決定は, 約 6 力月以上で, 誤嚥がひどく, 肺炎の合併した例で，再発の心配より も, 現在の肺炎の治療の必要があった例に施行した。
応答：門馬公経

声带手術を行った 4 例では誤嬹もとれ，シリコン注 入術で十分であった。声帯手術後右声帯麻痺をきたし た症例はあるが右頸部への再発が認められた症例であ つた。

\section{2）食道癌に対する非開胸食道抜去（Blunt Dis- section) の適応と術式について}

佐藤博信，田中 隆，河口忠彦，村山 公 安楽 励，須田清美，鈴木武樹，植田哲生 坂部 孝（日大第三外科）

食道癌に対しての開胸開腹による食道切除は手術侵 襲が過大であり，症例によっては心肺機能や術後合併 症の面から開胸開腹に耐えられない例がある。このよ うな症例に対して従来は食道切除を断念, by-pass 手 術，食道内挿管法などの姑息的手術を行ってきたが， 最近では非開胸による食道抜去, すなわち胸部食道の blunt dissectionを行っている。

昭和38年から60年 7 月までに当教室で経験した食道 癌症例は337例でこのうち切除例は137例である。昭和 50 年に非開胸食道抜去術を導入して以来, Ph-Ce 領域 12例, Iu-Im 領域 3 例, Ei-Ea 領域10例の計25例に行っ ている。術式としては，頸部胸部上部食道癌では頸部 郭清, 癌腫の遊離を行い開腹による下部食道の遊離切 離後 stripper を用いて上方に抜去している。

非開胸食道抜去の適応は，下咽頭頸部食道癌では上 縦隔への転移がなければ本法により全食道の切除で壁 内転移による再発をなくすことが出来もつともよい適 応である, 胸部上部食道癌, 頸部境界部食道癌では頸 部よりの郭清が可能であれば本法の適応であり, 胸部 中部食道癌では経腹的に用手剥離が困難で, $\mathrm{A}_{3}$ 症例な どでは危険も多く適応は少ない。胸部下部食道癌では 食道裂孔の開大により遊離郭清が或程度可能であり非 治療切除となるが一部の症例（開胸不能例など）に適 応がある。

以上当教室における非開胸食道抜去術の適応と術式 について報告した。

質問：鶴田至宏（大阪成人病センター耳鼻科）

後縦隔での食道再建と比べて, 前緹隔での再建はや はり安全なのか。

応答：佐藤博信（日大第三外科）

再建経路として後緹隔ルートは使用していない胸腔 内再発が起った時に再度狭窄が発生する危険がある。

質問：久保田元（浜松医大放射線科）

(1)再発部位は。

(2)術後照射もできないような肺機能障害例を適応と したのか。

応答：佐藤博信

(1)今回再発部位に対してのデーターはまとめなかっ たが，印象としては上縦隔再発が多いようである。

(2)術後放射線照射はしていない。

\section{3）下咽頭頸部食道癌の治療成績}

内田正興，河西信勝（癌研頭頸科） 加藤孝邦 (慈大耳鼻科)

1969～1984年の間に癌研を受診した下咽頭頸部食道 癌201例について, 治療成績を中心に種々の検討を行な った。 
症例の内訳は PS 84例, PC 60例, Ce 41例, PW 16例 であり, 症例の約 7 割は stage III〜IV の進行例であっ た。

治療法は術前照射に加えて咽喉食摘を行ない，これ に種々の程度の頸部郭清, 甲状腺切除, 上縦隔郭清を 併用した。ただし stage I〜II では放射線根治照射を行 なったものもある。

手術は全例 201 例中の 112 例 $55 \%$ に行ない，その 5 年 生存率は $33.5 \%$ であった。

これを部位別でみると，PCが最もよく，KaplanMeier 法で $50.4 \%$ の生存率であり, 次いで PW 41.7 \%, PS 26.1\%, Ce 10.4\%であった。これを切除標本 における転移の有無で生存率をみると，PN $(-)$ 群で は50\%強の 5 年累積生存を示すのに対して PN (+)群 では僅か $10 \%$ 台の生存であった。部位別生存率で PS が不振であったのは頻発する転移によるものと考えら れた。

次に手術後の死因では断端再発は手術例112例中 8 例と少なかったが，ルビエル転移，肺転移等，手術領 域外への転移が全死因の約 $40 \%$ を占めた。

また重複癌も多く全症例の $17 \%$ に達し，特に PS で は $25 \%$ にみとめられ，これらも予後を悪くする因子で あった。

このように本領域の癌治療は非常な困難を伴うもの であるが，リンパ節郭清の徹底化を計ることにより， 1969～1979年の成績28.6\%を1980～1984年の手術成績 41.9\% (Kaplan-Meier 法 5 年生存) に向上させること ができており，多少の光明が見出せるに至っている。

質問：村上 泰 (慶大耳鼻科)

手技のことで，胸骨柄を取った場合と，上方から用 指切除するものとのあいだで，切除しうる範囲に差が ないと思うがどうか。

応答：内田正興（癌研頭頸科）

上縦隔の郭清は胸骨柄をおとさなくても郭清できる 例が多いが，時には上縦隔深く meta のある例もあり， 今後も胸骨柄切除を続行するつもりである。また，本 法施行により原発巣を余裕をもって切除できる。

質問：天津睦郎（神大耳鼻科）

術前 $\mathrm{N}_{0}$ に対する治療方針について。

応答：内田正興

原則として $\mathrm{N}_{0}$ でも全例 RND を行なう。

質問：遠藤光夫（医歯大第一外科）

(1)食道への重複癌は, 多中心性発育の癌といえるか。 (2)郭清（上縦隔）の下限はどこまでするのか。

応答：内田正興

(1)食道の同時多中心性癌は除外してある。

(2) Paratracheal の郭清は PC, Ce, Ce〜 Iu では必ず 行ない, 郭清範囲は腕頭動脈の基部の高さまでである。

質問：奥田 稔（日医大耳鼻科）

(1)根治手術不能例とは。

(2)頸部食道と下咽頭にわたる症例とをどちらに分類 しているか。

\section{応答：内田正興}

(1)手術を行なわなかった症例は, inop. の $\mathrm{N}_{3}, 75$ 歳以 上の高齢者，アルコール中毒の者で家族のいない者， 等である。
(2) $\mathrm{Ph}$ か $\mathrm{Ce}$ かの区別は摘出物, X 線上の所見から占 居部位の大きい方を原発巣としている。

追加：真栄田宗慶（埼玉がんセンター耳鼻科）

食道吻合部 web を形成した症例はケロイド体質も 関与していると思われる。

\section{第34群 形成（1）}

座長 茂木 五郎 (大分医大耳鼻科)

124）D-P 皮弁による一期的下咽頭食道再建法 玉城 進，大村正樹，本庄 䉷 (京大耳鼻科)

下咽頭喉頭食道摘出後の下咽頭食道再建の皮弁法に は, 筋皮弁法, free flap 法, 胸部島状皮弁法, deltopectoral flap(D-P 皮弁) 法，複合皮弁法，pectoral arcade 法, Conley 法などがあるが，我々は，D-P 皮弁による 一期的な下咽頭食道再建法を考案し臨床的に良好なる 結果を得ている。今回は，その手術手技について報告 した。その特徵は次のと扔りである。

1) 頸部の切開線と D-P 皮弁を垂直切開線にて連 続させる。

2) 下咽頭喉頭食道摘出後に, 通常の D-P 皮弁 slit 法で下咽頭及び食道と·D-P 皮弁を縫合する。Slit から $3 \mathrm{~mm}$ 下方を最下点として弯曲する線と, 頸部切開線 と一致する線に囲まれた $\mathrm{D}-\mathrm{P}$ 皮弁基部の上皮を脱上 皮し，同部位を縫合して，食道を再建する。 $\mathrm{D}-\mathrm{P}$ 皮弁 に隠れた鎖骨部の皮膚は皮弁として持ちあげて，rotation して胸部の cover に用いる。

3 ）頸部の皮膚をもとの位置にもどして，D-P 皮弁 を覆い, D-P 皮弁の脱上皮されていない部位と縫合す る。胸部の raw surfaceには，大腿から遊離皮弁を移 植する。

質問：内田正興（癌研頭頸科）

我々も数例試みたが，いずれも敗した。この 2 例は 長期観察例か。

応答：玉城 進（京大耳鼻科）

1 例目は 6 力月， 2 例目は 4 力月の経過で，瘻孔は 無い。食道透視でも異常なく,ファイバースコープで, 皮弁下端までの直接確認が可能である。

質問：茂木五郎（大分医大耳鼻科）

術前照射を行った症例か。

応答：玉城 進

2 症例とも術前照射を行っている。PMMCによる 再建の経験が 1 例あるが，皮弁がひらいてしまったの で，その後は行っていない。

125）前腕皮弁法による下咽頭頸部食道再建術の検 討

真栄田宗慶，苦瓜知彦，竹生田勝次

(埼玉がんセンター耳鼻科)

野崎幹弘（女医大形成外科）

昭和 50 年 11 月より 60 年 7 月までに当センターでは, 下咽頭頸部食道再建術を29例施行したが，術式は局所 皮弁法 9 例, 大胸筋筋皮弁法 6 例, 食道抜去胃管挙上 法 2 例, 遊離空腸法 6 例扔よび前腕皮弁法 6 例であっ た。このうち前腕皮弁法は下咽頭癌 3 例，頸部食道癌 1 例, 喉頭癌術後再発 1 例および喉頭癌術後咽頭狭窄 1 例に対して適用し，その各種成績，長所，短所等に 
つき検討した。

手術は 5 例が一期的に行なわれ, 喉頭癌術後再発で 前頸部皮膚を切除し, DP 皮弁で被覆した 1 例は二期 的に切り離し術が施行された。術後，DM コントロー ル不良で廔孔形成したのが 1 例，消化管出血が 1 例あ つたが，皮弁壊死はなかった。原則的に一期的再建の ため, 経管栄養終了が平均 26.3 日で比較的早期の経口 摂取，術後照射が可能となる。また侵襲が少なく高齢 者にも適用でき，薄くて口経や形状のトリミングが比 較的容易なため, 死腔発生を減少させ，特に中咽頭上 端まで切除した例にも適応し得た。しかし, 筋皮弁で は筋が一種の緩衝带となっているのに対して前腕皮弁 は薄いために周囲痏痕性変化の影響を直接的に受けて 伸展性に欠け，照射によりそれが増強されると思われ る。また採取できる皮弁の大きさに限度があり, 前腕 部の醜形が残り若年者には適応しにくいことが久点で ある。吻合部狭窄は断端を斜めにしたり，波型にした りして縫合面を広くとる土夫により軽減され得る。

質問：茂木五郎（大分医大耳鼻科）

遊離弁は何時間被置しておいてもよいか。

応答：真栄田宗慶（埼玉がんセンター耳鼻科）

術後吸引不良で DM 合併例で廔孔形成した例は, 開 放創洗浄とテラマイガーゼ圧迫により肉芽増生した。 その後特に吻合部狭窄は強くない。

質問：高橋正紘（女医大耳鼻科）

前腕皮弁は一般に薄いので食道発声に有利と思われ るが，先生の症例では如何か。

\section{応答：真栄田宗慶}

前腕皮弁法を始めて日が浅く症例も多くないが，食 道発声の習得がよいような印象を受ける。

126）下咽頭癌術後唾液瘻に対する有茎筋弁を用い た閉鎖手術

村上 泰，館野秀樹，藤村昭子，浦尾爾須子 中山尚樹（慶大耳鼻科）

大胸筋皮弁法による再建手術を行うようになってか ら，術後唾液㾞の発生頻度は激減したが，ときに，大 量照射後の症例に対する再建の後でみられることがあ り，その閉鎖に難渋することがある。自然閉鎖を待つ と約 2 力月の長期間を要し, そのあいだ経口摂取がで きないため,早期閉鎖が望ましいのだが, 今日までよい 方法は皆無であった。局所皮弁法ではまず閉鎖は不可 能で, DP 皮弁と組合わせて用いても, 小瘦孔の再発生 をみることが多い。筋皮弁では厚すぎて, 特に照射後 の皮下線維化の著しい症例では利用できない。

そこで我々は，血行のよい有茎筋弁を利用すること によってよい結果を得ることができた。

まず内腔の上皮化のために, 㿉孔周囲の最も状態の よい皮膚を hinge flap として, 細いナイロン糸で閉鎖 する。この上に, 有茎の大胸筋や下方茎胸鎖乳突筋を 用いて補強する。さらにその上に，小さな前胸壁有茎 皮弁を rotate して周囲の皮膚と縫合し，一期的に閉鎖 手術を完成させる。前胸壁の皮虐欠損はそのまま寄せ て縫合する。

筋を被うべき有茎皮弁を利用できない時には，筋層 の上へ直接に中間層遊離植皮をしてもよい。特に前頸 部の皮膚が不足している症例に対して有効である。
唾液瘻が感染を伴い, 周囲皮膚の条件がわるい症例 にも応用できる確実な方法で，大胸筋を犠牲にするだ けの価值がある。取り出すのに難があるが，広背筋の 一部を用いることもできる。

㾞孔の再発したものはないが，嚥下圧で危険と思わ れる場合は, 経鼻的低圧持続吸引で脱気してやるのが よい。

質問：鶴田至宏（大阪成人病センター耳鼻科）

筋弁と食道内腔となる皮弁との縫合は疎に行うの か, 密に行うのか。

質問：行木英生（国立杤木病院耳鼻科）

再建管腔の上方で瘻孔ができた場合は，頸動脈が死 腔, 㾞管腔に露出して非常に危険な状態に陥ることが あるが，このような場合の閉鎖手術に何か上い工夫は ないか。

応答：村上 泰（慶大耳鼻科）

(1)Hingeにする皮弁と筋弁とは縫合しない。

(2)胃腸管によるつり上げ術後の㾇孔は咽頭端に生じ る。Hinge flap と小さな DP 皮弁で閉鎖できる。

127）腐蝕性食道狭窄に対する遊離腸管による再建 野崎幹弘, 笹本良信, 平山 峻 (女医大形成外科)

羽生富士夫, 吉田 操, 今泉俊秀, 村田洋子 (女医大消化器病センター外科)

遠藤光夫 (医歯大第一外科)

われわれは難治性の腐蝕性食道狭窄に対しその再建 に遊離腸管移植を併せ行ない，良好な結果を得た 2 症 例を経験したので報告した。

症例 $1 ： 44$ 歳男性。16歳のとき濃硫酸ガス吸入によ り腐蝕性食道炎と診断される。その後次第に狭窄症状 が増強し，他院にて28歳のとき胸骨後食道胃間結腸有 茎移植術施行。術後, 吻合部縫合不全を来し, 以後 2 回にわたり再手術施行したが通過障害は改善をみ始ま ま経過した。昭和 57 年 4 月, 当センターにて全身状態 の改善を計るべく腸瘻より栄養管理。昭和58年 9 月新 たな食道再建のため, 胸壁前食道有茎結腸間の欠損部 分 $(22 \mathrm{~cm})$ に遊離空腸移植術施行した。

症例 $2: 38$ 歳女性。22歳のとき自殺企図で硫酸を飲 む。1 年後臙下困難のため他院にて胃瘦造設, 長期に わたる経腸的栄養管理をしていた。昭和 60 年 1 月当セ ンターにて食道再建施行。胸壁前胃管に $13 \mathrm{~cm}$ の遊離 空腸移植を併せて下咽頭への吻合を行うことが出来 た。

1980年よりわれわれの経験した遊離腸管移植による 種々の食道再建は35例。その多くは咽頭喉頭頸部食道 摘出後の再建例であるが, 症例によって胸部 (Iu, Im) に抢よぶ食道再建にも本法が適応されつつある。症例 を通して術式の実際と若干の文献的考察を併せて述べ た。

\section{第35群 形成（2） \\ 座長 森満 保 (宮崎医大耳鼻科)}

128）甲状腺を用いて食道皮膚瘻を閉鎖し得た 1 症 例 戸島 均, 加藤 功 (山形大耳鼻科) 大島義彦，朝比奈一三，立味理恵 
（山形大整形外科）

我々は外傷性頸推脱臼骨折に伴う頸部食道皮膚瘦に 対し，甲状腺を用いて閉鎖し得た症例を経験した。

症例：27歳男性。昭和59年 6 月 16 日屋根より落下, 近医にて $\mathrm{C}_{5}, \mathrm{C}_{6}$ 頸推脱臼骨折による完全四肢麻痺の 診断で同日 $\mathrm{C}_{4}$ から $\mathrm{C}_{6}$ までの減荷手術と頸推前方固 定術を受けた。術後 2 週目より頸部皮膚に発赤をきた し, 術創を再開空すると膿汁排泄をみ, 以後膿汁は止 まらなかった。 8 月 6 日頸推体前方感染巣の debridement を行った際, $\mathrm{C}_{5}$ 椎体前方の食道壁に $1 \mathrm{~cm}$ 程度の 裂創を認め縫合した。しかし絶食，IVH，経管栄養を 行うも食道皮膚瘻は閉鎖せず，11月 5 日当院整形外科 転院となった。

左頸部輪状軟骨の高さで，胸鎖乳突筋にそって直径 約 $1 \mathrm{~cm}$ の㿉孔開口部あり, 嚥下運動に伴い唾液が流 出した。食道造影では食道入口部付近左後壁より造影 剂がもれ， $\mathrm{C}_{5}, \mathrm{C}_{6}$ 椎体欠損部の死腔から皮膚への流出 を認めた。

昭和59年12月11日, 気管切開の後, 全麻下に食道鏡 施行, 食道入口部左後壁に瘦孔を確認した。頸部皮膚 横切開にて食道後面に入り椎体の壊死, 肉芽組織, 腐 骨を搔爬後, 食道壁の瘻孔を確認, 粘膜下に二層縫合 した。食道壁の補強，死腔の充鎮の目的で，左上甲状 腺動脈及び周囲軟部組織を柄とした甲状腺左葉を回転 し, 頸椎体死腔に挿入した。

術後13日の食道造影では瘻孔はなく，その後経口摂 取を開始した。甲状腺機能は正常で CT にて甲状腺の 生着を確認できた。経過はきわめて良好で, 現在元気 に rehabilitation 中である。

129）気管再建術後の治癒に関する実験的検討

長谷川宏，謝 家明，吉田隆一郎，川原克信 綾部公懿, 富田正雄 (長大第 1 外科)

気管再建術後の治痖過程を明らかにすることによ り，縫合不全の予防および吻合部狭窄の防止をはかる ため次の実験を行なった。

実験 1 。雑種成犬を用いて頸部気管にて 3 軟骨輪切 除後気管再建術を施行し術直後, 術後 7 日目, 21 日目 に屠殺し吻合線 $1 \mathrm{~cm}$ あたりの抗張力を縫合系をつ けたまま測定した。

実験 2 . 吻合条件をかえて頸部気管再建術を施行し た。A群は 3 軟骨輪切除し吻合部張力を $100 \mathrm{~g}, \mathrm{~B}$ 群は $8 \sim 12$ 軟骨輪切除し吻合部張力を $400 \mathrm{~g}, \mathrm{C}$ 群は $14 \sim 17$ 軟骨輪切除し吻合部張力を $1000 \mathrm{~g}$ とした。術後 7 日目, 21日目に屠殺し吻合線 $1 \mathrm{~cm}$ あたりの抗張力を縫合系 を抜系後測定した。また, マイクロアンギオグラフィ 一, 組織所見像についても検討した。

結果 1 ) 実験 1 では全例吻合部抗張力は $1.2 \mathrm{~kg}$ 以上 に保たれた。21日目でも縫合糸の有無にて抗張力に差 があり縫合系が抗張力に関与していた。2）実験 2 で は術後 7 日目の吻合部抗張力は各群間に差はなかった が吻合条件のよいと思われた $\mathrm{A}$ 群に比へ吻合条件の悪 いと思われた B，C群に高い傾向がみられた。3）マ イクロアンギオグラフィーと吻合部抗張力の対比では 造影良好なものに抗張力が大きかった。4）組織所見 像では術後 7 日目に既に上皮で覆われるが多列繊毛上 皮で円柱上皮は術後21日目で出現した。5）粘膜下層
の線維の増生は $\mathrm{A}, \mathrm{B}$ 群は軽度であったが $\mathrm{C}$ 群で増生 が著明な例がみられた。これは吻合部にかかる張力に 対する生体反応であり吻合部狭窄に何らかの関連があ ると考えられた。

以上より術後21日目で吻合部の治癋はほぼ完成する と思われた。

130）微小血管吻合術による各種再建法の適応につ いて

\section{永原國彦，新木 隆，三浦 誠 \\ (国立京都病院耳鼻科)}

微小血管吻合術の応用により頭頸部外科術後の再建 はより機能的で自由度の高いものとなった。有茎皮弁 で届き難い位置の広範囲再建も自由であるから充分な 摘生術により,治癒率の向上が期待されるべきである。

Free groin flap 以外は血管吻合は容易であるが吻合 部に余計な緊張や屈曲がかからぬように全体のデザイ ンを考える必要がある。遊離皮弁, 空膿等の生着に対 する最大の因子は recipient たる頸部血管の状態であ る。適当な recipient が期待出来なければ通常の再建 をとるべきである。

今迄の自験 free groin flap 20例, free D-P flap, forearm flap, free jejunum 14症例の分析から, 頸部 全道や広範囲な口腔内の再建には free jejunum が, 可 動部舌にはforearm flapが, 舌全摘後にはfree PMMC flap が，美容的には free groin flap が適当と 考えられるが, 最終的には腫湯摘出が終った段階で柔 軟に考えるべきであろう。

再建に対する配慮が腫崵摘出術の根治性を落すよう なことがあってはならない。

質問：横山道明（鳥取大耳鼻科）

Free forearm flapの大きさは小さいものではどの くらいまでが安全か。

応答：永原國彦（国立京都病院耳鼻科）

舌可動部に対しては $6 \times 7 \mathrm{~cm}$ 以下の大きさの前腕 皮弁は経験していない。非常に少さいものは舌に関し ては適応がないのではないかと考える。

\section{1）気管物性一第 2 報一}

川島明美，矢原三十美，林崎勝武，金子敏郎 (千大耳鼻科)

〔目的〕気管吻合術の成否は, 気管の伸展可能範囲に 左右される。個々の症例における伸展可能範囲を術前 に知るための手段として，伸展可能範囲と密接に関係 している気管動的弾性率を測定した。犬摘出気管を用 いた実験成績は第36回本学会において報告したが，今 回第 2 報としてヒト気管における in vivo での成績を 報告した。

〔原理〕気管のように塑性変形を伴う弾性体の動的弾 性率を表わす Yerzley resilience (Y.R. と略す) を， 衝撃波を与えた際に生ずる自由振動減衰曲線より求め る。

[方法]ヒト頸部気管直上より単発矩形波による衝撃 波を与え, その振動様式を超音波パルス Mモード変法 により記録し, 得られた減衰曲線より Y.R. を計測し た。対象は $13 〜 77$ 歳の男女計 35 名で，気管自然位及び 伸展位における Y.R. を求め, 加齢による変化を検討 した。その際頸部の角度 (頸軸とOM-line のなす角度) 
を測定し，頸部の伸びやすさの目安とした。

〔結果〕伸展位と自然位の気管 Y.R. の比 (Y.R. 比) は, 0 ～19歳で1. 15, 20～39歳で1. 12, 40～59歳で1.08, 60 歳〜で 1.05 と, 年歯が増加する程低值を示した。こ れらを頸部の伸びやすさで 3 つのグループに分類する と, 39歳以下では頸部の伸びやすさの違いによる Y.R. 比の変化はあまり見られず，40歳以上では頸部の伸び やすいグループでは Y.R. 比が高值で，伸びにくいグ ループ程低値を示した。前回発表の犬摘出気管を用い た実験結果では，ホルマリン硬化気管は新鮮気管より Y.R. 比が低值を示しており, 七ト気管の加齢による変 化は犬における新鮮気管とホルマリン固定気管との関 係と類似の相関関係を示した。これよりヒト気管の加 齢による硬化が推測された。

〔まとめ〕超音波パルス法を用い，ヒト気管 Y.R. を 測定し, 加歯による気管物性の変化を推測し得た。

\section{第36群 咽頭・食道一良性疾患（1） \\ 座長 小松崎 篤 (東邦大耳鼻科) \\ 132）下咽頭良性腫瘍の治療経験 \\ 堤 浩二, 山岨達也, 大西由美子 (東大耳鼻科) \\ 新美誠司，廣瀬 肇（東大音声研）}

我々は最近，下咽頭血管腫の 1 例を経験したので, 過去 10 年間における当科外来及び本邦における下咽頭 良性腫瘍について若干の文献的考察を加えて報告し た。

我々が経験した症例は52歳, 男性。昭和 59 年 5 月, 食後咽頭異物感を生じ，半月後消失。同年 12 月，集団 検診で胃カメラ挿入できず，精査奨められ，昭和 60 年 2 月28日当科受診。既往歴・全身所見に特記すべき事 なし。間接喉頭鏡にて，右披裂部から右梨状陷凹にか けて示指頭大・紫褐色・柔かそうな桑実状の境界鮮明 な腫瘤を認めた。食道造影にて右梨状陥凹に示指頭大 の腫瘤と思われる陰影が認められた。

以上の所見より下咽頭血管腫を疑い，全麻下に咽頭 側切開を行ない，明視下にて出血もなく摘出した。病 理学的には海綿状血管腫だった。（大きさは $25 \times 15 \times$ $10 \mathrm{~mm}$ )

下咽頭の良性腫陽は極めて稀で，G. Kelemen によ れば，咽頭良性腫瘍の $0.1 \%$ にすぎず，当科外来におい ては過去 10 年間にこの 1 例のみであった。本邦におけ る報告例は，我々が調べ得た範囲では，本例を含めて 26例にすぎなかった。組織学的分類は, 線維腫 9 例, 血管腫 7 例, 脂肪腫 4 例, 神経鞘腫 3 例, リンパ管腫 1 例, 内皮細胞腫 1 例, 奇型腫 1 例で, 線維腫, 血管 腫が比較的多かった。

なお，今回の調査結果には，のう胞，ポリープなど は除外し，真性の腫湐に限った。

また，26例中にも実際には中咽頭と思われる症例も 含まれており, 厳密に下咽頭良性腫瘍というと, さら に少なくなるものと思われる。

質問：内田正興（癌研頭頸科）

文献上，大出血をきたした例はあるか。

応答：堤 浩二（東大耳鼻科）

過去の文献で下咽頭血管腫について「出血し易い」
「大出血に注意」という記述は多いが，実際に出血があ ったという報告は見当らない。

133）下咽頭部に発生した Hemangiopericytoma 西山禮二，桜井一生，小島秀嗣，石原正健 岩田重信（藤田学園耳鼻科）

下咽頭部および食道部に発生する腫湟のうち，良性 腫湢は比較的稀で，大部分は悪性腫瘍（特に扁平上皮 癌)である。下咽頭良性腫瘍の出現頻度は, G. Kelemen によれば咽頭良性腫瘍 1000 例に対し 1 例の割合である という。

血管周皮細胞腫は比較的頻度の少ない非上皮性腫瘍 で，我々が集計した数は自験例も含め235例であった。 しかし下咽頭発症例は見当らず最初の報告と考えられ る。今回我々は下咽頭腫瘍の診断にて摘出術施行した ところ benign hemangiopericytomaとみなしうる所 見が得られた稀なる症例を経験したので報告した。

症例は47歳女性，半年続く咽喉頭異常感を主訴に近 医受診。下咽頭腫湯指摘され生検施行したところ悪性 疾患は否定されたが，精査すすめられ当科受診。受診 時，左梨状窩より表面平滑，暗赤色，可動性のある有 茥性ポリープ様腫瘍を認めた。食道造影にて左梨状窩 より発生を疑わせる腫瘤影認め, 喉頭造影で同部は陰 影欠損を呈した。CT scanで左梨状窩にびまん性に enhance される腫瘤影を認めた。耳鼻頸部に異常認め ず，頸部リンパ節も触知しなかった。以上より左梨状 窩側壁より発生した良性腫瘍と診断し，NLA 全麻下， 喉頭直達鏡使用し腫瘍摘出術を行った。この際術中, 術後の出血はほとんど認められなかった。本腫湟は組 織学的に benign hemangiopericytoma と診断され, 術後 6 力月経過した現在, 再発, 転移等認めず経過観 察中である。

本邦で経験された hemangiopericytoma 中, 今回が 初めてと考えられる下咽頭発症例を経験したので若干 の文献的考察を加え報告した。

質問：小松崎篤（東邦大耳鼻科）

この種の血管に富む腫瘍では CT scan が診断上有 用と思われるが，CT scan を行なうに至った経過につ いて知りたい。

応答：西山禮二（藤田学園耳鼻科）

喉頭, 食道造影だけでは後部への広がりが不明確な 為, CTを撮った。

質問：新美誠司（東大音声研）

経内視鏡的に摘出する場合，出血等が処置し難いと 思う。その点どう考えて，本術式を選択されたか。

応答：西山禮二

外切用アプローチの方が，安全とは考えたが，近医 での probe 時ほとんど出血を認めなかったこと，可動 性に富み下咽頭ポリープと診断し直達鏡下の手術で充 分摘出できると考えた為，外切開はしなかった。

質問：保喜克文（札幌医大耳鼻科）

(1)既往歴でなにか発生要因に結びつくものがあった 力。

(2)術中に feeding artery が確認できたか。

応答：西山禮二

(1)既往に慢性甲状腺炎はあるが詳細は不明である。

(2)栄養血管と思われる血管は認めなかった。 
134）特発性食道破裂の 3 症例

須田清美, 田中 隆, 佐藤博信, 河口忠彦 村山 公, 安楽 励, 増田英樹, 谷 真弓 八ツ橋輝海，坂部 孝（日大第 3 外科）

特発性食道破裂は, 1724年 Boerhaaveにより報告さ れて以来，比較的まれな疾患とされてきたが，最近増 加傾向にある。今回我々は, 早期診断により食道破裂 部を fundic patchにより治療せしめた症例を経験し た。また当教室における過去の 2 症例の発症, 治療経 過についても比較検討したので報告する。

(症例 1 ) 54 歳男性。昭和 47 年 6 月 23 日吐下血を主訴 に近医受診。同夜吐血著明となり, 胸部痛も出現し近 医入院。入院後食道胃透視にて食道破裂と診断され, 6 月 29 日当院入院。入院後直ちに腸瘦造設, 胸腔内ド レナージ施行するも，2 週間後に死亡。

(症例 2 ) 36歳男性。昭和 45 年 9 月 13 日より左胸部痛 上腹部痛出現し近医受診。上部消化管穿孔の疑いにて, 9 月17日当院入院。来院時ショック状態で, 腹部X線 にて横隔膜下中央に気泡を認め, 食道破裂と診断した。 全身状態を考慮し, 胃㾞造設, 縦隔ドレナージ, 左胸 腔内ドレナージ施行するも，第 3 病日に死亡。

(症例 3 ) 48歳男性。昭和 60 年 5 月 17 日吐血, 上腹部 痛, 呼吸困難が出現し, 近医受診。上部消化管穿孔の 疑いにて, 当院入院。来院時顔面苦悶状。胸部X線に て綐隔気腫を認め, ガストログラフィンによる食道胃 透視にて下部食道より胸腔への造影剂の漏出を認め, 食道破裂と診断。破裂部の fundic patch 施行し， 2 力 月後に軽快退院。

以上当教室における 3 症例の発症, 治療経過につい て報告するとともに, 早期䛦断と適切な外科的処置に ついて，文献的に考察した。

追加 田中 隆 (日大第 3 外科)

本症例は下部食道の穿孔部の上方に筋層のみの断裂 があった。発症の原因として急激な食道内圧の上昇が 考えられるが，筋層の断裂がどうしておきたか興味あ る症例である。

\section{第37群 咽頭・食道一良性疾患（2） \\ 座長 冨田寛 (日大耳鼻科) \\ 135）非クロストリジウムによるガス産生性口腔底 蜂窝織炎の 1 症例}

金子まどか，西本喜胤，柊 光一，持松いづみ 大石公直，澤木修二（横市大耳鼻科）

非クロストリジウムによるガス産生性感染は，E． Coli, Streptococcus, Klebsiella などによって生じる 重篤な感染症である。その多くが基礎疾患をもち, 糖 尿病性壊疽として下肢にみられた例がいくつか報告さ れているが，頭頸部領域では未だ報告例をみない。今 回われわれは, E. Coli, Lactobacillus などの混合感染 により皮下にガス産生を認め, 下咽頭へ瘻孔を形成し た口腔底蜂窩織炎の 1 症例を経験したので, その経過 を示し，若干の考察を加えて報告した。

(症例) 42 歳男性, 両側顎下部腫脹の主訴で受診した。 2 週間前より発熱し, その後耳下部から顎下部に腫脹 が広がった。治療せず放置していたところ, 口腔内出 血および血性膿汁の排出と呼吸困難が出現したため,
昭和 60 年 4 月 13 日緊急に入院した。入院時, 頸部全体 が腫脹し, 捻髪音を触知した。口腔底は強く発赤腫脹 し, 一部に瘦孔を形成し, 悪臭のある血性膿汁の排出 がみられた。開口障害があり, 喉頭ファイバースコピ 一では, 中・下咽頭側壁の腫脹, 喉頭蓋の浮腫状腫脹 と, 喉頭蓋谷に出血に伴う気泡の排出がみられた。頸 部単純X線でガス像を認め, 臨床検査では白血球増多, 核左方移動, 血小板減少, 肝機能々腎機能の低下, 血 糖值の上昇, 血沈の六進が認められた。緊急に気管切 開し, 補液, 抗生剂投与を続けたところ, 下顎部に波 動が認められ,同部を切開すると多量の排膿を認めた。 細菌検査では, E. Coli, Lactobacillus などが検出され た。この膿瘍は下咽頭にも通じていたが，抗生剂投与 により徐々に膿瘍や瘻孔が縮小し, 約 3 か月後気管孔 を閉鎖することができ，軽快退院した。

非クロストリジウムによるガス産生性感染は頭頸部 領域ではまれな疾患で, 今までに報告例をみない。進 行が早く, 気道狭窄をきたす危険性もあるので, 早期 診断と適切な処置が必要であることを強調した。

質問：栫 博幸 (自衛隊中央病院耳鼻科)

1. 感染経路はどのように考えるか。

2. 歯の状態はどうであったか。

3. 血液培養ではどうであったか。

4. 肝機能, 腎機能の低下をどのように考えるか。

応答：金子まどか(横市大耳鼻科)

1，2．明らかな外傷様歯はなかった。

3. 血液培養では病原菌は検出されなかった。

4. 初診時, 強度の脱水, 全身状態の低下, pre DIC の状態で，それによる肝・腎機能障害であったと考え ている。

136）成人の咽後膿瘍の 2 症例

大平泰行 (帝京大耳鼻科)

石塚洋一，前田秀彦，長井大二，木村元俊 (帝京大溝口病院耳鼻科)

最近当科で経験した成人の咽後膿瘍の 2 症例を報告 した。

症例1。41歳女性。主訴は, 與下障害, 咽頭痛, 構 音障害, 呼吸障害。現病歴は, 昭和 59 年 3 月中旬上り 徐々に, 咽頭痛, 嚥下障害, 構音障害が出現し, 近医 耳鼻科にて咽後膿瘍と診断され治療を受けていた。し かし, 症状は軽快せず夜間呼吸困難も出現したため, 6 月 2 日当科を紹介され入院となった。既往歴に, 肺 結核, 頸部リンパ節結核がある。初診時, 中咽頭後壁 及び左側下咽頭後壁の著明な膨隆があり, 頸部には, 多数のリンパ節を認めた。ツ反は中等度陽性, CRP 陰 性, 白血球数は正常であった。結核性咽後膿瘍の診断 のもとに, SM, INH, RFP, EB の併用療法及び咽後 膿瘍の穿刺排膿を行なった。穿刺液からは, 結核菌, 一般細菌ともに検出されなかった。症状は徐々に軽快 し, 初診 1 力月後には退院となった。退院後も, 外来 にて抗結核療法を続けているが，経過は良好である。

症例2.47歳男性。主訴は, 咽頭痛, 嚥下障害, 構 音障害, 発熱。現病歴は, 昭和59年12月 1 日より発熱, 咽頭痛が出現し, 12 月 3 日には, 嬩下障害, 構音障害 が出現, 食物攝取も困難となった。12月 4 日, 当科受 診し即日入院となった。既往歴に糖尿病がある。初診 
時, 左側咽頭後壁は著明に膨隆しており，また左前頸 部の腫脹および頸部りンパ節の腫脹を認めた。血液検 查では, 血沈穴進, 白血球数増加, CRP $4+$, 空腹時血 糖 $283 \mathrm{mg} / \mathrm{dl}$ であった。糖尿病に合併した咽後膿瘍と 診断し，抗生物質の投与扔よび糖尿病のコントロール を開始した。局麻下に切開排膿を行ない多量の膿汁を 吸引した。その後症状は急速に改善し，初診より17日 後に退院となった。

今日では, 成人の咽後膿場は稀となっているが，今 回，結核性のものと糖尿病に合併した症例を経験した ので報告した。

質問：藤原久郎（長大耳鼻科）

結核性咽後膿瘍の診断は難しいと思うが，この症例 は原発か, 続発性のものか。膿汁から結核同定は難し いが，結核菌が出にくい理由はどう考えるか。

応答：大平泰行（帝京大耳鼻科）

結核性咽後膿瘍例では, 菌の検出を認めなかったが その理由は不明である。反省点として, 咽後膿瘍の内 腔の生検を行うべきだった。

137）幼児, 副咽頭腔および縱隔膿瘍の 1 例

猪狩武詔，藤井みゆき，增野博康，鈴木理文 山本 渉（横浜市立市民病院耳鼻科）

咽後膿場は最近の抗生物質の進歩により，余りみら れなくなった疾患であるが，時には呼吸困難，緹隔洞 内への進展など, 重篤な症状をひきおこし, 我々耳鼻 科医としては素早い対応が要求される。今回我々は, 幼児の副咽頭吵より上縱隔におよぶ膿瘍を経験したの で報告した。

症例は 1 歳 11 力月の男児。昭和 57 年 6 月 20 日，歯ブ ラシをくわえたまま転倒し，口内をつき，出血，嘔吐 があったが救急病院で様子をみるように言われた。翌 朝, $40^{\circ} \mathrm{C}$ 発熱, 頸部腫脹があったため某病院受診し, 紹介され, 来院した。初診時, 頸部は右方へ側屈し, 腫脹，皮下気腫があった。口内所見として，前口蓋弓 に約 $1 \mathrm{~cm}$ の穿孔のあとが認められたが, 咽頭後壁, 側 壁の腫脹はなかった。頸部 X-Pにて頸椎前軟部組織, 両側側頸部組織陰影の拡大，ガス貯留像を認め，外傷 性咽後，側咽頭間隙膿瘍および気腫と診断し，抗生剂 大量投与による保存的治療を始めた。1 週間の治療に ても発熱は $40^{\circ} \mathrm{C}$ と続いて全身状態も悪化した。 $\mathrm{X}-\mathrm{P}$ 検 查で右上縦隔に膿揚腔の形成がみられた。全麻下に前 頸部切開にて排膿，上縦隔への drainage を施行した が, 翌日 drainよりミルク残渣の排泄があり, 咽頭穿孔 が疑われた。咽頭精査により，下咽頭後壁，披裂レ心゙ ルに穿孔を認めた。前頸部の創より洗浄を行い，ポル トバックチューブを挿入し，持続吸引を行った。同時 に経管栄養チューブを挿入した。術後 3 日目にて下熱 し, 全身状態も徐々に改善した。術後 7 週目で経口摂 取可能となり，8週目で退院した。退院後の経過は順 調である。

咽後膿瘍は筋膜間吵相互の関係より縦隔への波及も きたすことがあり，生命の危険にさらされる。頭頸部 領域の筋膜, 筋膜間吵に関する知識, 十分なる精查, 時期を逸さない治療が必要である。

138）縦隔炎及び膿胸を併発した頸部食道毠室の 1 治験例
橋口一弘, 岡田康司

(済生会神奈川県病院耳鼻科)

前中由己，堀之内宏久

(済生会神奈川県病院外科)

最近我々は硬性上部食道鏡検査後, 咽後膿瘍から縦 隔膿瘍, 左膿胸へと進展した食道息室の 1 症例を経験 したので報告した。

症例：71歳女性

初診：昭和 60 年 2 月 18 日

主訴：血痰

既往歴：第12胸椎骨折 (58歳), 頸椎捻挫 (69歳)

現病歷: 本年 1 月中旬より時々盃一杯程度の血疾を 認め, 近医より精査目的にて当科紹介される。耳・鼻・ 咽喉頭, 胸部及び頸部 X-Pに異常所見なし。2 月22日 硬性上部食道鏡検查を施行。同日夜より咽頭痛出現。 食事摂取困難となり, 近医で抗生剤等投与されるも軽 快せず，2月25日当科受診。喉頭左外側に圧痛を認め, 間接喉頭鏡にて, 左梨状窩及び下咽頭後壁が発赤, 腫 脹していた。頸部X-Pにて retropharyngeal space の 拡大とガス像が認められ，咽後膿瘍と診断し， 2 月 26 日入院となる。

入院後経過：抗生剤に上る保存的治療にて症状の改 善がみられない為，2 月27日左頸部皮切により，prevertebral space に達し排膿した。同時に施行した硬性 上部食道鏡検査にて下咽頭, 食道入口部, 頸部食道に 裂隙は認められなかった。術後 4 日目より左胸部痛を 訴え, 胸部 X-Pにて, 左下肺野に異常陰影を認めた為, 胸部外科依頼。縦隔膿瘍及び左膿胸と診断され, 胸腔 ドレーン挿入。胸腔内洗浄を続けつつ, 保存的治療を 施行。その後徐々に軽快し，5月24日軽快退院となっ た。経口捸取開始後の食道造影にて, 頸部食道息室が 認められた。

この症例の経過及び治療などについて報告した。

質問：遠藤光夫（医歯大第一外科）

Divertikulitis という診断は以前からの症状でばど んなことでつけられるのか。

応答：橋口一弘（済生会神奈川県病院耳鼻科）

以前より血痰を認めていたので，息室があるのでは ないかと推察した。

質問：鶴田至宏（大阪成人病センター耳鼻科）

食道鏡施行前に食道造影は行なっていないのか。

応答：橋口一弘

初診時, 再診時も食道造影は行なっていない。

\section{第38群 気道一良性疾患 (1) \\ 座長 戸川 清(秋田大耳鼻科)}

\section{9）Laryngomalacia $の$ 臨床的観察}

大沼秀行, 山下公一, 王 増勤, 高野正美 (金医大耳鼻科)

Laryngomalacia は生後間もない時期に見られる強 い気道狭窄を示す病態で，小児の気道トラブルの中で は60〜80\%を占めると言われている。然し多くは小児 科領域で扱われ，局所の状態を詳しく観察されないま まに処理されてきており，喉頭の病態の詳細な記載は あまりなされていない。Holinger は全麻下で直達喉頭 鏡下に喉頭を展開し観察しているが，喉頭の構造の動 
きを伴う狭窄を的確に観察することは不可能である。 我々はこのような症例を含む気道障害について小児外 科, 小児科, 新生児室の対診を受け, 過去 10 年間, 咽 喉頭の表面麻酔のみを行ない，ビデオ録画ができるフ アイバースコープの装置を用いて気道狭窄の病態の診 断を行ない，共同でこれらの症例の管理をしてきてい るが，その資料の中から laryngomalacia 症例につい て考察した。

症例は24例(男14例，女10例)。症状は吸気時に起こ る気道狭窄による喘鳴が主体で，チアノーゼを伴った 症例が 7 例, 哺乳障害をともなったものは16例あった。 発症は多くは生後比較的早く起こっており, 呼吸量の 急激な増加に伴い顕著となっている。特に未熟児が多 いということはないが，合併奇形が比較的多いのが特 徵的である。喘鳴の持続期間は 6 力月以内に半数以上 は消失しているが， 2 年以上持続した例もある。長期 間持続した例はいずれも Pierre Robin 症候群の症例 であった。喉頭所見は(1)主として epiglottisに問題が あるタイプ，(2)披裂部あるいは披裂喉頭蓋七ダに問題 があるタイプ，(3)両者が合併したタイプの 3 つに分類 できた。Epiglottic type はさらに（i ）喉頭蓋が $\Omega$ 型 を呈し, 吸気時に両側縁が後内方に入り込んで気道を 狭窄する場合と（ii）epiglottis 自体が虚弱で，吸気時 に喉頭腔内に翻転して気道を狭窄するタイプとがあっ た。

質問：坂倉康夫（三重大耳鼻科）

粘膜の過剩形成である arytenoid type と喉頭蓋に 問題のある epiglottic type を laryngomalacia の下に 分類可能力。

応答：大沼秀行 (金医大耳鼻科)

McSwiney は omega-shaped epiglottis, aryepiglottic fold, arytenoid type の 3 型に分類している。

質問：日野原正（獨協医大気食科）

本症に対する積極的治療法について。

応答：大沼秀行

当科で観察された 24 症例に関しては，気管切開を含 む手術症例は無い。

質問：鈴木 徹 (今治市, 開業耳鼻科)

嚥下困難を伴う症例も少なくないと思うが如何か。

応答：大沼秀行

哺乳障害, 体重増加不良は24例中17例に認められ， feeding tube 等の処置が必要と考える。

\section{0）先天性脊椎・骨端異形成症 2 症例における喉頭 \\ 発育形成不全}

大井秀哉，渡辺行雄，吉田行夫，浅井正嗣

水越鉄理（富山医薬大耳鼻科）

海木玄郷（富山医薬大整形外科）

先天性春椎, 骨端異形成症は, 1966年 Spranger らに よって報告されて以来, 整形外科領域においては数及 の報告がなされている。本疾患の身体的特徵は，(1)小 人症, (2)胸部樽状変形, (3)腰椎前彎が著明であること, (4)扁平脊椎, (5) X線学的に近位骨端部の病変が高度な ことがあげられている。

今回, 私達は, 本疾患に伴うと考えられる, 喉頭発 育形成不全の 2 症例を経験したので若干の考察を加え て報告した。な抢，今回報告する 2 症例は兄弟であり，
本疾患は遺伝性を有するとされている。

症例 1 は39歳男性で四肢の筋力低下, 膀胱直腸障害 にて当院整形外科に入院の患者であった。身長 $85 \mathrm{~cm}$, 頭部の発育は正常, 知能正常であり, 他の報告でみら れるような近視, 網膜剝離, 口蓋裂, 感音難聴等の合 併症は認められなかった。頸椎症に対して全麻下手術 施行後, 抜管困難となり呼吸状態悪化のための当科を 受診した。喉頭ファイバーの所見で, 喉頭蓋の右方へ の偏位，喉頭腔全体の狭小化，披裂部および仮声帯の 著明な腫脹がみられたため, 緊急気管切開術を施行し た。頭部の発育が正常なため相対的に下顎が突出して いること, 頸部が短いこと, また頸部伸展不能なこと などのため十分に視野が得られなかった。症例 2 も同 様に気管切開術を施行する際に十分な視野が得られな いこと，気管へ到達するまでの距離が長いことなどの 障害を伴った。現在, 両症例とも呼吸状態の回復がみ られ気切口は閉鎖しているが，気管切開には充分術後 管理を念頭に入れて注意する必要があるものと考察し た。

質問：戸川 清（秋大耳鼻科）

成人になるまで呼吸困難がなく，また術後，短時日 で症状が消褪しているが，直接原因は何か。

応答：大井秀哉（富山医薬大耳鼻科）

これまでには強い呼吸困難は認めておらず，小人症 であることと関連して喉頭形成不全の程度が致命的な ものではなかったためと考えられ，頸椎症のために症 状が表面化したものと考える。

\section{1) Kartagener 症候群の 1 例}

稲垣政志, 斎田 哲, 久保将彦, 間島雄一 坂倉康夫 (三重大耳鼻科)

梅本正和，青木謙三（松阪市民病院小児科）

最近当科において経験した Kartagener 症候群の 1 例を報告した。

患者は 1 歳 2 力月の女児。慢性副鼻腔炎, 気管支拡 張症, 内臟逆位がある。鼻粘膜生検による電顕所見で はすべての線毛の cross section において inner dynein armの欠損が認められた。Outer dynein arm, radial spoke 等はほほ正常であった。光学電気的測定法 による線毛波と線毛打頻度測定の結果は, 多数の位相 を示す線毛波が混在して扔り，線毛打頻度の測定は不 可能であった。つまり線毛打のばらつきは本例におい てきわめて大であり, Pederson \& Mygind らの分類で は grade III に相当するものと思われ, 規則的かつ協調 性のある線毛運動は障害されているものと考えられ た。

\section{2）気管憩室例とその発生学的一考察}

日野原正，平林秀樹，越井健司，大垣治幸 高津忠夫，秋山欣治，添田 弘 (獨協医大気食科)

気管支鏡施行中ごくまれに気管壁に先端が盲端とな っている気管悡室を見ることがある。気管憩室の文献 的検索と発生機序につき, 動物発生学的な観点から考 察を述べた。

症例：24歳男性，血痰にて昭和54年 6 月当院内科に 入院，気管支鏡依頼にて当科を受診した。局麻下に気 管支鏡検查を施行したところ，気管分岐上 $2.5 \mathrm{~cm}$ の 
気管右側壁に直径約 $7 \mathrm{~mm}$, 深さ約 $6 \mathrm{~mm}$ の先端が盲 端となった気管息室を認め, 気管支造影を施行した。

考察：気管息室の成因については，従来先天性（真 性), 後天性（内圧性ならびに牽引性）に分類されてお り, 先天性憩室のうち気管下部後方の膜様部との移行 部に好発するものの成因は，気管支が崩芽時のまま残 存した不全発育気管支とされている。

大迫による23例の本邦気管・気管支憩室報告例のう ち，右気管壁にみられるものが12例あるが，1例を除 いて気管分岐部上 $10 \sim 40 \mathrm{~mm}$ の高さにある。

演者らは, 気管分岐部上 $20 \sim 30 \mathrm{~mm}$ 部の気管右壁に みられる憩室については, 動物系統発生学的見地から, これを気管気管支 (tracheal bronchusまたは accessory bronchus) の遺残と考えることが妥当とし, その 根拠としてブタ,ウシの類ではそれぞれ気管分岐部上, 約 $3 \mathrm{~cm}$, 約 $10 \mathrm{~cm}$ 上方の右気管壁より肺胞を有する気 管支が必ず存在することを動物の解剖で示した。

結語：以上よりヒト気管下部の右側壁にみられる喤 室は, 憩室ではなくて, 動物の系統発生学的見地から 気管気管支 (tracheal bronchus) の遺残と考えるのが 妥当とすることを述べた。

質問：戸川 清 (秋大耳鼻科)

本症は耳鼻科医の間ではあまり知られていないと思

うが，他科では比較的よく知られているか。

応答：日野原正（獨協医大気食科）

臨床的に本例が確認されるようになったのは，気管 支鏡検査, 気管支造影が行え, 胸部外科を行うように なってからである。小児科領域では内視鏡検査の機会 も少ないので，報告例は少ないものと考える。

\section{第39群，気道一良性疾患（2） \\ 座長 馬場 駿吉 (名市大耳鼻科) \\ 143）特異な局所所見を呈した喉頭真菌症 2 例 花田武浩, 内䄇明裕, 坂本邦彦, 昇 卓夫 (鹿大耳鼻科) \\ 近年, 抗生物質による菌交代現象や，抗腫瘍剤， ス} テロイド剤使用による宿主の抵抗力減弱状態, 免疫不 全状態等に伴う全身的な真菌感染症の発現が重要な問 題となっている。

今回，我々はステロイド剤を長期間連用していた患 者における特異な局所所見を呈した喉頭真菌症を経験 した。症例を呈示するとともに，若干の文献的考察を 加え報告した。

症例 1 は，33歳女性。昭和57年より潰瘍性大腸炎に 䍜患し，59年結腸亜全摘術を受け，一時軽快するも再 然し,プレドニゾロン $5 \mathrm{mg} / \mathrm{d}$ を維持量として服用中で ある。

昭和59年 8 月より, 慢性副鼻腔炎で加療していたが, 60 年 4 月中旬より, 嗄声が出現した。当初, 喉頭内は 軽度発赤を認めるのみであったが，経過観察中に左仮 声帯に肉芽病変を認めるようになったため, biopsy を 行い, 真菌感染症の存在が確認された。Amphotericin $\mathrm{B} に よ る$ 含嗽, ネブライザー治療を続けたが, 改善傾 向がえられないために, contact YAG-laser を用いて， 病変部を焼灼した。

症例 2 は, 51歳女性。昭和56年より RA に罹患し,
以後現在に至るまで，プレドニゾロン $10 \mathrm{mg} / \mathrm{d}$ を維持 量として内服している。

59 年 1 月から, 嗄声が出現し, 同年11月に当科を受 診している。初診時, 左声帯にポリープを認め, 60 年 4 月, MLSを施行し切除した。ポリープの内部には, 膿栓を認め, 病理組織診断により真菌感染症の存在が 確認された。その後の経過は良好で, 現在に至ってい る。

144）胸部に著変のなかった喉頭結核の 2 症例

柊 光一，金子まどか, 古川政樹, 持松いづみ 佃守, 大石公直, 澤木修二

(横市大耳鼻科)

結核症は肺結核のみならず，耳鼻咽喉科領域におい てもその有病率が低下していることは周知の通りであ る。しかしそのために，かえって診断がむずかしくな り, また他臓器特に肺に結核性病変が認められず, 他 方いわゆる肉芽腫型を示すものが多いため, 喉頭癌と の鑑別上問題となる症例が増えている。最近われわれ は胸部に著変を認めず, はじめ喉頭癌を疑い組織診で 喉頭結核と確定した 2 症例を経験したので報告した。

症例 $1 ： 57$ 歳, 男性。59年 3 月末より誘因なく嗄声 が出現し，増悪傾向を示した。同年 4 月近医より喉頭 癌の疑いにて紹介され受診した。初診時左声帯に一部 白色病変を伴った肉芽様病変がみられ，全身麻酔下に 生検したところ, 慢性炎症の所見であった。しばらく 経過を観察したが，改善せず，同年 8 月に再生検した ところ, 肉芽腫様炎症とのことで, ツベルクリン反応 などより喉頭結核と確定した。喀痰の抗酸菌培養は陰 性で, 胸部X線写真でも陳旧性の病変であった。早速 抗結核凧の 3 者併用療法を施行したところ, 喉頭所見 が改善した。

症例 $2: 59$ 歳, 男性。60年 3 月より徐々に嗄声が出 現し, 同年 4 月当科初診した。初診時右声带に肉芽様 病変がみられ, 喉頭癌を疑い全身麻酔下に生検したと ころ, 肉芽腫様炎症であった。その後の喀痰培養にて 抗酸菌陽性と判明し, 喉頭結核と確定した。胸部 X線 写真では陳旧性の病変であった。現在抗結核㶡の全身 投与を施行中である。

この 2 例を含め最近 10 年間で当科 9 例の喉頭結核症 例を経験した。いずれも肉芽腫型だったが，胸部 X線 写真や喀痰検査より早期に診断がつき, 初診後 1 力月 以内に治療が開始できたが, 今回の 2 症例は組織診に てはじめて確定したために $2 \sim 4$ 力月かかった。現在 では稀な疾患となった喉頭結核は，特に喉頭癌との鑑 別上重要と思われた。

質問：坂本邦彦（鹿大耳鼻科）

最近局所原発で肺病変を伴わない耳鼻咽喉科領域の 結核症が増加しているが，この理由についてどうか。

応答：柊 光一 (横市大耳鼻科)

胸部X線写真上現われない肺結核に続発した管内性 伝染と考えた。

質問：藤沢成人（高松市，開業耳鼻科）

治療は，局部の所見がどの程度になるまで続けるべ きか。

応答：柊 光一

所見的には $1 \sim 3$ 力月で軽快がみられたが, 肺内病 
変の存在する可能性も考え, 1 年間, 抗結核療法を続 けた。

質問：馬場駿吉（名市大耳鼻科）

結核が判明するまで同室に入院患者がいる場合があ るが, 院内感染予防に対する対策をしたか。

応答: 柊 光一

今回は LMS のための短期入院であった。

145）カニューレ抜去が困難な喉頭気管気管支炎の 1 例

池田 朗, 野井 理, 川上理郎，宇野 功 高橋宏明 (阪医大耳鼻科)

症例：43歳女性。主訴：軽度呼吸困難。現病歷：59 年 3 月, 咳を主訴に某院呼吸器科受診。気管支鏡にて 喉頭より気管に及ぶ粘膜の軽度浮腫状肥厚が認められ た。抗生剤等の投与にて, 一般状態が軽快したにもか かわらず，喉が詰まる感じが持続したため，大阪医大 耳鼻科を紹介された。

初診時所見: 喉頭室粘膜が浮腫状に腫脹し仮声帯も 膨隆を認めた。他に耳鼻科的に著変はなかった。喉頭 室脱出症と診断した。

入院後経過：59年10月25日全麻下喉頭微細手術の施 行を試みたが，声門狭窄が著しく插管不能にて中止。 改めて11月 1 日, 局麻下気管切開の上, 再度手術を試 みた。仮声帯, 喉頭室, 声門下腔の粘膜が著しく腫脹 しており, 可及的にも切除した。なお, 気管切開時に 気管壁の肥厚を認めた。

術後経過：同日深夜，呼吸困難が出現。気管により ファイバースコープを指入したところ，カニューレ先 端より気管分岐部まで気管粘膜が全周性に著しく発 赤, 浮腫状に腫脹し, 内腔には泡沫状の粘稠な分泌物 が充満していた。このため分岐部直上までチューブを 插入，気道を確保した。ステロイド大量投与にて症状 は軽減したが, 以後 3 力月間に同様の症状が 3 回出現, 呼吸管理およびステロイド大量療法を必要とした。60 年 3 月からはプレドニゾロンの長期投与を開始し, 徐々に投与量をへらし, 現在は 1 日 $10 \mathrm{mg}$ を続行中で 呼吸困難発作はみられない。しかし, 気管粘膜の腫脹, 声門, 声門下腔の狭窄は持続し, 現在カニューレ抜去 困難の状態にある。

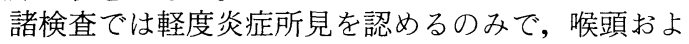
び気管粘膜の組織像も単なる炎症像であった。

以上の症例を報告した。

質問：馬場駿吉 (名市大耳鼻科)

感染菌と思われる細菌の検出はなかったか。

応答：池田 朗（阪医大耳鼻科）

細菌検査で特にこれといった菌は出なかった。

追加市村恵一（都立府中病院耳鼻科）

浜松医大在籍中に同様の症例を経験し，教室の芹沢 が耳喉に発表しているので参照されたい。やはり治療 上の決め手がなく難渋した。

\section{6）成人の急性喉頭蓋炎}

市村恵一, 村上 泰（都立府中病院耳鼻科）

田中秀夫 (浜松医大耳鼻科)

本邦では小児の急性喉頭蓋炎をみることが極めて少 ないため，ときどき遭遇することのある成人例の方が 頻度は多い。しかし, 成人の急性喉頭蓋炎の報告は意
外なほど少なく，本邦でも昨年迄にわずか 50 例しか報 告がない。本年になって札幌医大などからまとまった 例数が示されており, 本疾患が再認識されるべき時期 にきたといえよう。そこで，われわれが浜松医大で昭 和53年から59年までに経験した 18 名（19例）に, 都立 府中病院で本年 4 月から半年間に経験した 4 名の計 22 名（23例）の急性喉頭蓋炎の症例について検討した。 22 名の内訳は, 男子14名, 女子 8 名と男子に多く, 年齢は25歳から60歳に分布し, 30 代, 40代にピークが あった。39歳男子に再発例があったので延べ23例とな った。ほとんどの症例で咽頭痛, 嚥下痛がみられ, 発 熱や頸部の圧痛も多い症状であった。呼吸困難は 2 例 のみにみられた。症状発現から来院までの期間は 1 日 $\sim 3$ 日が最も多く, 欧米の報告例よりも遅い傾向があ った。喉頭蓋は発赤・腫脹しているものが大半であっ たが，小児のようなりーセージ様の腫脹と異なり，凹 凸のみられるものが多く, また中には浮腫状腫脹を呈 する例もあった。血液培養で細菌は 1 例も検出されず 小児例とは異なった。治療は11例が入院して抗生剤 ( $\mathrm{AB}-\mathrm{PC}$ またはPZ-PC)の点滴静注をうけ, 全例が気 道確保の必要もなく治瘜している。12例は外来通院の みで, 抗生剤 (AB-PC ゃ CCL) の内服を主に治療さ れていた。

呼吸困難や敗血症症状が早期に進行する重篤な小児 例とは臨床像が異なっており, 早期に発見して抗生剂 治療を行えば予後はきわめてよい。発症後 3 日目まで 無治療であったものが 6 例あり， 2 例は呼吸困難が出 現し，4例は喉頭蓋に潰崵を認め(膿場が自潰したの か？）この数字は一つの切れ目と考えられる。治療の 開始は早いに越したことがないが，遅くとも 3 日目ま でには開始すべきである。

追加：坂倉康夫（三重大耳鼻科）

本疾患による呼吸困難のための死亡例を追加した。 本症治療における喉頭乱切の意義はどうか。

応答：市村恵一 (都立府中病院耳鼻科)

呼吸困難を呈する症例は文献的にも本邦では欧米に 比し少ない。

呼吸困難の強い症例でも気道を確保しさえすれば乱 切の必要なく抗生剤のみでコントロールしうると考え る。

\section{第40群 反回神経 ( 1 )}

座長 村上 泰 (慶大耳鼻科)

147）喉頭反射における求心性インパルスの観察 森川郁郎, 進 武幹, 前山忠嗣, 梅崎敏郎 吉田太，岩永康成（佐賀医大耳鼻科）

喉頭反射, 特に嚥下時における喉頭防御反射は呼吸, 発声と共に喉頭の重要な機能であり,この防御反射に は咽頭, 喉頭の知覚が関与していると考えられる。そ こで，今回我々は，この知覚の主な求心路と考えられ る上喉頭神経ならびに反回神経の求心性インパルスを 実験的に観察し検討した。

実験動物はネコを用い，上喉頭神経は迷走神経本幹 より分枝した部位で, 反回神経は輪状軟骨下縁より約 $3 \mathrm{~cm}$ 尾側でそれぞれ切断して観察記録した。また，随 時甲状舌骨筋の筋電図ならびに声門下圧を同時記録し 
た。なお，嚥下は咽頭注水により惹起させた。

上喉頭神経の求心性インパルスは喉頭, 気管粘膜の 表面刺激および喉頭の圧迫で増加するが, 前者は表面 麻酔で抑制され，後者は抑制されなかった。また，嚥 下時, 注水とほぼ同時に discharge は増加し, 喉頭挙上 に一致して著明な discharge の増加がみられた。この 喉頭挙上時の discharge の増加は表面麻酔では抑制さ れず，主に深部知覚が関与していると思われた。

反回神経の求心性インパルスは喉頭, 気管の表面刺 激あるいは喉頭の圧迫ではいずれも上喉頭神経におい てみられたような増加は認められなかった。しかし， 胸郭の圧迫によっては著明な discharge の増加が認め られた。また, 嚥下時, 喉頭挙上一致してのみ dischargeの増加がみられた。

以上より, 上喉頭神経からは多くの知覚衝撃と考え られる求心性インパルスが観察され, これには少なく とも表在知覚性および深部知覚性の二つの異なった求 心性インパルス群が認められた。また, 反回神経の求 心性インパルスは全体的には喉頭, 気管などからの知 覚以上に，なんらかの胸郭からの変化に対応した求心 性インパルスが優位に観察された。

質問：久 育男 (京府医大耳鼻科)

Chemoreceptor な介したものについても実験を進 めていただきたい。

上喉頭神経内枝は声門部㧍よび声門上部，反回神経 は声門下部への知覚線維の系路と考えていたが, 今回 の結果ではこれらは否定的か。

応答：森川郁郎（佐賀医大耳鼻科）

上喉頭神経は今回の生理実験でも知覚に関してはか なり優位であり, 声門下, 気管の刺激でも discharge が みられる。反回神経は今回の実験では気管の知覚刺激 は上喉頭神経ほど優位ではないが，個々の fiber でみ ればあると考える。

質問：磯貝 豊（東電病院耳鼻科）

粘膜針刺激に伴う上喉頭神経の impulse の Burst が 2 段階になっているようにみえるが, adaptation に よるものか, または刺激が 2 回入っているのか。

\section{応答：森川郁郎}

上喉頭神経において dischange が粘膜刺激によっ て誘発されたスライドにおいて2峰性にみえたものは 針が 2 回粘膜に触れたためである。

\section{8）音刺激による家鬼の反回神経反射電位}

\section{児玉 実, 遠藤朝彦, 本多芳男} (慈大耳鼻科)

福原武彦 (慈大第二薬理学)

(目的) 音刺激により猫の反回神経に反射電位が発現 することが報告され, 発声のフィードバック機構との 関連が注目されている。今回私共は, 家兔を用い音刺 激による反回神経線維群の反射電位の観察を目的とし て音圧, 音の周波数を変えて与え, 反射電位を $\mathrm{ABR}$ と 同時に記録しそれらにつき比較検討した。

(方法)ウレタンとクロラロースを腹腔内注射した浅 麻酔下の家兔 16 羽を用いた。頸部反回神経を露出, 切 断し白金電極により遠心性の誘発電位を双極導出し た。ホーンスピーカーより刺激幅 $5 \mathrm{msec}$ のトーンバ ーストを刺激間隔 $238 \mathrm{msec}$ で与え, 誘発電位を750回
平均加算した。周波数は $0.25,0.5,1,2,3,4,6$, $8 \mathrm{kHz}$ を用いた。

(結果) 音刺激による家鬼の反回神経線維群の反射電 位は 2 相性の波形であり, 初めのピークは陽性で, ピ 一ク潜時は音刺激のトリガーから測定し 13〜18 msec 付近, 2 番目のピークは陰性で 20〜 $25 \mathrm{msec}$ 付近にみ られた。 $3 \mathrm{kHz} 5 \mathrm{msec}$ のトーンバーストを $110 \mathrm{~dB}$ $\mathrm{SPL} よ り 10 \mathrm{~dB}$ 間隔で音圧を下げて与えた時, 音圧の 減弱とともに反射電位の振幅は徐々に小さくなるがピ 一ク潜時には著しい遅れはみられない。また反回神経 反射電位の発現閾値は 70〜80 dB の間で ABR のそれ よりも約 15〜 $20 \mathrm{~dB}$ 高い。110 dB の音刺激を与え周波 数を 0.25 から $8 \mathrm{kHz}$ の間で各周波数について記録し た反射電位の波形においてピーク潜時，振幅などに著 しい変化はみられない。 $3 \mathrm{kHz} 110 \mathrm{~dB}$ の音刺激を20分 間連続して与え音刺激開始直後と 20 分経過後に記録し た反射電位の波形を比較するとほぼ同様の波形が得ら れ adaptationの傾向は生じ難いと考えられる。サイア ミラールの静注直後反射電位は減衰してみられなくな ったが, 20分経過後再び発現し biological な反応であ ると考えた。音刺激による家婜の反回神経線維群の反 射電位は動物の血圧低下, 麻酔深度, 徐脈などの影響 を受けて減衰し易くその発現が不安定なことを確認し た。

質問：澤島政行（東大音声研）

この反射は, 聴覚 specific のものと考えるか。

応答：児玉 実 (慈大耳鼻科)

他の感覚刺激でも反回神経に反射電位が生ずること が報告されている。今回の実験の反射電位と同一か否 か不明であるが，聴覚による喉頭反射は発声のフィー ドバック機構との関連が注目されている。

質問：磯見 豊（東電病院耳鼻科）

(1)ABR 第 1 波の潜時が長いようにみえるが，その 原因について。

(2)反回神経反射電位の時間が長いようにみえるが, 如何加。

応答：児玉 実

潜時から波形は artifact ではないと考える。波形の 性状様加算平均処理でないと明確な波形を観察できな かった。本実験方法で双極導出して得られた波形の

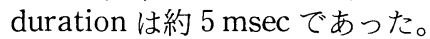

149）犬喉頭における Substance $\mathbf{P}$ 線維について 久育男, 竹内 章, 水越 治 (京府医大耳鼻科)

佐藤文彦（福井医大耳鼻科）

Substance P (SP) は, 従来知覚神経第一次ニュー ロンの神経伝達物質と考えられていたが, 現在では自 律神経系にも広く分布していることが知られている。 喉頭において, 知覚神経系はその反射機構に, また自 律神経系は腺分泌並びに血流調節に深く関与してい る。今回, 我々は犬喉頭における SP 線維の存在様式を 調べ, 喉頭の知覚, 自律神経系を理解する上で重要な 意味を有すると考えられる結果を得たので報告した。

実験には雑種成犬 6 頭を用いた。うち 3 頭は右反回 神経および右上喉頭神経内枝を各々喉頭入口部におい て挫滅, 24時間経過後灌流固定し, 各々挫滅した神経 
を摘出した。他の 3 頭は無処置のまま灌流固定し, す べての内喉頭筋, 並びに喉頭蓋, 喉頭室, 声門および 声門下部より粘膜を摘出した。これらの試料は後固定 後, cryostat にて薄切し, PAP 法による免疫組織化学 的手法を用いて処理した。本法の詳細については84回 日耳鼻総会において発表した如くである。

喉頭粘膜には，varicosity を有した多くの SP 線維 が検索した全ての領域に認められた。SPを有する上 皮細胞は存在しなかった。喉頭腺の領域にも少数の SP 線維が認められ，そのうちには喉頭腺を取り囲む ように走るものも存在した。喉頭神経については，上 喉頭神経内枝, 反回神経の両者に SP 線維が含まれて いるのが観察された。内喉頭筋内には SP 線維は存在 しなかった。

以上の如く $\mathrm{SP}$ 線維は喉頭においても, 知覚, 自律神 経系において重要な役割を担っていることが示唆され た。

質問：進 武幹（佐賀医大耳鼻科）

喉頭への自律神経のルートはどのように考えるか。 腺組織における SP 線維は副交感神経と考えてよい か。

応答: 久 育男 (京府医大耳鼻科)

上喉頭神経, 反回神経内には多くの交感神経線維が 含まれている。詳細については, 過去, 本学会におい て報告した。

$\mathrm{SP}$ 線維の腺組織内分布様式からみて, ノルアドレ ナリンとの共存の可能性が高い。

\section{第41群 反回神経（2）}

座長 本多 芳男 (慈大耳鼻科)

150）左反回神経麻痺を呈した胸部大動脈瘤の 4 症 例

\section{上出洋介，森山 寛，本多芳男 (慈大耳鼻科)}

前回の本学会で, 私共は当教室の反回神経麻痺症例 の統計的観察について報告し，主に特発性麻痺と悪性 腫瘍による麻痺について述べた。そのなかで, 特発性 麻痺と思われた中に悪性腫瘍による麻痺が多く認めら れた事から, 特に左反回神経麻痺においては, 縦隔陰 影と重なる部位の検索には積極的に CT スキャンを施 行すべきである事を指摘した。その後も反回神経麻痺 症例の検索を続けてきた結果, 胸部大動脈溜による反 回神経麻痺症例を経験した。反回神経麻痺をきたす原 因の中でも胸部大動脈瘤による麻痺は一般的によく知 られているが，文献的には $0.6 \%$ 3.4\% と原因別頻度 からみればむしろ少ないものといえる。最近の 1 年間 で当科を初診とした胸部大動脈瘤による左反回神経麻 痺 4 例を経験したが, これらは初診時胸部 X線写真か ら 2 つ群に分けることができた。すなわち胸部X線 写真より容易に大動脈瘤を疑わせる所見を得た群と, AP window 部の腫瘤を疑い, 積極的に CT スキャン, MRI (magnetic resonance image) を使用しながら も悪性腫瘍の疑いにて試験開胸した結果，胸部大動脈 瘤と診断された群である。

前者 2 例は胸部X線写真, CTスキャン, MRI にて充 分動脈瘤を確認できるものであった。それに対して，
後者 2 例は近医耳鼻科にて特発性反回神経麻痺として 治療され，かつ初診時胸部X線像に抢いても，ほぼ正 常所見を示していた。Contrast CT においては上行， 下行大動脈の間に腫瘤陰影を認めたが enhance され ず, MRIにおいても動脈瘤としての血管腔を形成して いなかったことからボタロ管リンパ節の腫脹と診断し 試験開胸をおこなった。結果は動脈瘤の内部がほとん ど血栓によって占められているボタロ管起始部に発生 した動脈瘤であった。

胸部X線写真で正常と思われても，高齢者において は特に胸部 CT スキャンの必要性を認めることを動脈 瘤症例を通じて再認識した。

151）小児声帯麻舫の予後

小河原昇, 古川 滋, 石橋 康

(神奈川こども医療センター耳鼻科)

大石公直，澤木修二(横市大耳鼻科)

〔目的〕小児の声帯麻痺は成人と比較すると稀であ る。当センターにおける小児声帯麻痺症例について, その臨床像と麻痺おょび嗄声の予後との関係を検討し た。

〔対象〕昭和 45 年より 59 年までに神奈川県立こども医 療センター耳鼻咽喉科で診察した声带麻痺の小坚 50 例 (男27，女23例) である。

〔結果〕麻痺の発症時期は生下時が25例で半数を占 め, 6 力月までが38例である。麻痺側は左側が 34 例, 右側が 8 例, 両側が 8 例である。成因は特発性と考え られたもの 24 例，心疾患によるもの 8 例，その術後に 生じたもの13例，頸部抢よび食道の術後に生じたもの 3 例，その他 2 例であった。

6 力月以上経過観察できた 38 例の予後を検討した。 声帯麻痺は16例が完全に回復し，6例が不完全回復で, 回復しなかったものが16例であった。特発性では19例 中11例が完全， 3 例が不完全回復を示した。心疾患の 術後に生じた 10 例では完全回復 4 例, 不完全回復 2 例 で，概して悪かった。その他の成因の例では予後不良 のものが多かった。完全回復までの期間は，16例中11 例が 6 カ月以内であった。しかし 2 年以上を要した例 も 3 例認めた。

嗄声の予後は, 消失 27 例, 改善 6 例, 不変 5 例であ つた。改善以上の軽快率は特発性が最もよく,ついで 心臓に関するものであった。声帯麻痺が回復しなかっ た16例中11例で, 嗄声の消失または改善を認めた。こ れは健側の代償によるものである。

〔まとめ〕小児の声帯麻痺50例につきその臨床像拉よ び予後を検討した。声帯麻痺は $58 \%$ で完全または不完 全回復を示した。麻痺は早期に回復する例が多いが, 2 年以上たって回復する例もみられた。小児では健側 声帯の代償機能がよいためか, 嗄声に関しては87\%が 消失または改善した。

質問：澤島政行（東大音声研）

ここで特発性といわれている麻痺の中に，分婏時の 圧迫や毫引によるものがかなりあると思われるが，そ の点は如何。

応答：小河原昇 (神奈川こども医療センター耳鼻科)

特発性の中に, 分婏外傷などが含まれている可能性 があると考える。 
質問：市村恵一（都立府中病院耳鼻科）

5 年たって回復していた症例があったが何故これほ どたってから回復してきたのか。

応答：小河原昇

障害された神経が，長期間かけて再生したものと考 える。

質問：久 育男(京府医大耳鼻科)

特発性両側麻痺 6 例の予後については如何。 応答：小河原昇

両側性麻痺の予後は, 完全回復 2 例, 不完全回復 4 例, 不変 2 例である。

\section{2）挿管性声帯麻㾇22症例の娭討}

樋口晶子，金子まどか, 柊 光一, 古川政樹 大石公直，澤木修二(横市大耳鼻科)

症例は1970年 1 月から 84 年12月までの 15 年間に，当 教室で経験した插管によると考えられる声帯麻痺22例 である。年齢は $20 \sim 82$ 歳で 40 歳代が 8 人と多く, 性別 は男10例，女12例で差はみられなかった。

初診時の所見では, 麻痺側は左18例, 右 2 例, 両側 2 例で左が多く, 麻痺の程度は固定しているもの16例, 制限がみられるもの 5 例，不明 1 例であった。固定位 置は副正中位 11 例，正中位 3 例，中間位 1 例，開大位 1 例であった。

19例は当大学病院で全麻下に手術をうけたもので, 全例カフ付きカニューレを用いている。 3 例は他院よ り術後紹介されたもので麻酔の詳細は不明である。手 術の種類は外科 14 例, 婦人科 4 例, 泌尿器科 2 例, 脳 外科 2 例で，外科では反回神経に直接関係のある甲状 腺, 胸部の手術を除いている。麻酔時間は 2 時間10分 から 6 時間 20 分で， 3 時間以上のものが16例と大半を 占め, 既に指摘される点と一致する。插管の難易度は 麻酔医が容易と判断したものが15例と多く，困難が 2 例, awake intubation が 1 例で, 插管操作の難易とは 関連性が少ないようである。麻酔方法，筋弛緩剤につ いても特記される点はみられなかった。

発症はほぼ全例とも手術直後より嗄声を訴えてお り，初診までの期間は 6 ～29日と幅がみられるが，麻 㽻の程度と日数には相関はみられないようである。回 復まで追跡できた 11 例はすべて 3 力月以内にほぼ完全 寛解した。これも今までの報告と一致するものである。

上記の自験例に文献報告例を加えて，麻酔時間と回 復までの期間，年齢と回復までの期間について検討を 加えた。前者では相関をみとめなかったが，後者では 40歳以上と 40 歳未満のグループで，45日以上と 45 日未 満につきカイ自乗検定イエーツの補正をおこなったと ころ危険率 $5 \%$ で有意差がみられ, 40歳以上では回復ま での期間が40歳末満より長くなる傾向がみられた。

質問：牛嶋達次郎（東大分院耳鼻科）

(1)麻酔時のカフ圧, 麻酔深度（バッキングの有無な

ど）についてはどうだったか。

(2)年次的な発生頻度などの推移は如何か。

応答：樋口晶子(横市大耳鼻科)

(1)カフ圧については検討していない。Backingの強 い症例も 2 例みられた。

(2)年代別には特に増加・減少はみられず平均してい た。
質問：磯貝 豊 (東電病院耳鼻科)

麻醉時にチューブを口角固定すると思われるが，右 口角固定が多いのではないかと想像される。左側麻痺 が多いこととチューブの口角固定位との関係について は如何か。

応答：樋口晶子

口角固定で，固定側におこるという例はなく検討し ていない。

153）声帯麻瘴の原因精査における CTスキャンの 有用性

古川政樹，金子まどか，柊 光一，樋口晶子 玉虫 昇, 大石公直, 澤木修二 (横市大耳鼻科)

声帯麻痺症例をみた場合まず重要なことは，原因疾 患，とくに悪性腫湟の検索である。十分な精査をする ことなく, 安易に特発性麻痺と診断することは避けな ければならない。そこで今回われわれは, 反回神経単 一の障害がみられた症例で，迷走神経本幹および反回 神経の走行にそった腫瘍性病変を早期に発見するた め, 頸胸部の CT スキャンをスクリーニング検査とし ておこない，若干の知見を得たので報告した。

対象は昭和 59 年 9 月から 60 年 6 月までの 10 力月間に 当科音声外来を受診した声带麻痺症例26例のうち, 術 後性など原因の明らかなもの，当科受診前に悪性腫瘍 の存在がわかっていた例を除いた11例である。このう ち 7 例に神経の走行にそった部位に何らかの腫瘍性病 変を認めた。内訳は甲状腺腫瘍 3 例, 肺腫瘍 3 例, 縦 隔腫瘍 1 例で，残る 1 例は原発巣不明の頸部りンパ節 転移によるものであった。これら 7 例のうち 2 例は, 頸部触診, 胸部 $X$ 線検查, 下咽頭食道造影などで明ら かな異常を認めず, CTスキャンで初めて異常所見がみ られた。残る 4 例は腫瘍性病変を認めず，特発性麻痺 と診断された。

代表的症例：59歳，女。昭和 59 年 8 月より嗄声が生 じ，当科を受診した。喉頭所見では左声帯が副正中位 に固定していた。頸部触診上異常なく, 頸静孔撮影, 胸部単純 X線検查, 下咽頭食道造影でも異常を認めな かった。CT スキャンを施行したところ, 上縦隔に腫瘍 性病変を認め, このための左声帯麻痺と考えられた。 諸検査の結果，悪性胸腺腫の診断で，放射線療法を施 行した。

声帯麻痺の原因精查, とくに悪性腫瘍の検索に CT スキャンがスクリーニング検査として重要であり, 積 極的に施行する必要があることを強調した。われわれ の経験では, CT スキャンは, 従来の検査では見逃され る可能性のある縦隔病変の精査にとくに有用であっ た。

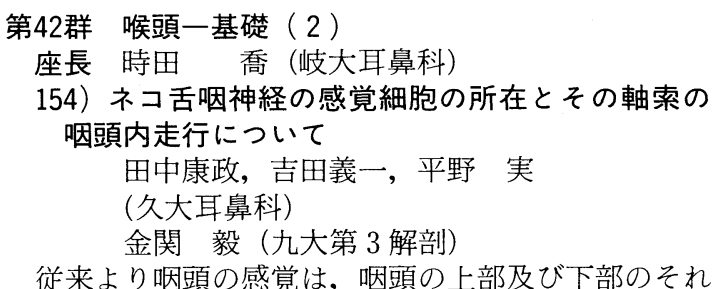


ぞれの一部を除いては舌咽神経により支配されてい る。しかしながら従来の研究法では舌咽神経が混合神 経である為に, この神経の感覚線維のみの走行並びに 分布については不明確である。第36回本学会で共同演 者の吉田が，ネコ喉頭の感覚神経線維の走行並びに分 布について報告したが，今回我々は，以下に述べる方 法によってネコの舌咽神経の感覚神経細胞の所在とそ の軸索の咽頭内走行について検討した。

〔実験〕 1. 舌咽神経の頸部本幹に HRP を注入し 標識される細胞体の所在を検索した。2，1で確認し た部位にWGA-HRP を注入し,舌, 咽頭内に標識され る感覚神経線維の分布と走行を凍結連続切片を作製す る事により検索した。

〔結果〕1. 舌咽神経頸部本幹への HRP 注入によ り舌咽神経上及び下神経節の細胞が標識された。 2 . 舌咽神経上及び下神経節への WGA-HRP 注入により 延髄内では，孤束核楔状束核の腹外側部，三叉神経脊 髄路核の背外側部に標識終末が認められた。しかし， 咽頭筋の運動神経終起始核及び副交感性起始核の細胞 体は標識されていなかった。従って，咽頭内に見られ る標識線維は感覚神経線維と考えられる。3. 舌咽神経 上及び下神経節への WGA-HRP 注入により咽頭内に 認められた標識線維は,(1)注入側と同側性に出現した。 (2)口蓋扁桃下極の高さで咽頭側壁に入った太い標識線 維束は，吻側方向には，舌根部及び軟口蓋へ尾側方向 には喉頭蓋谷へ, 後方には咽頭後壁に向う 4 枝に分れ る。(3)これらの標識線維の分布は, 耳管開口部, 上咽 頭, 軟口蓋 (主として尾側半分の口腔, 鼻咽腔面), 舌 (有郭乳頭より尾側)，口蓋扁桃周囲，舌根部，喉頭蓋 谷, 喉頭蓋咽頭面及び咽頭後壁に認められた。(4)吻尾 方向において，上咽頭耳管開口部の高さより，前壁で は, 喉頭蓋谷, 後壁では披裂喉頭蓋ヒダの中央の高さ に相当する咽頭後壁まで分布していた。

質問：時田 喬 (岐大耳鼻科)

舌咽神経知覚枝は教科書では lingual-tonrillar branch, pharyngeal branch が記述されているが，報 告では 4 つに分れるとのことであった。分枝をどのよ うに理解したらよいか。

応答：田中康政（久大耳鼻科）

舌扁桃枝は，頸動脈洞枝，咽頭枝，茥突咽頭筋枝を 分枝後の舌咽神経の名称である。本研究で 4 本に分枝 を分けたのは，その舌扁桃枝が粘膜下に入ってからの 走行により分類を行った。

質問：久 育男 (京府医大耳鼻科)

HRP 神経節内注入例で孤束的に終末を認めていた が，その分布の特徵（孤束核内でのレベル，局在）に ついて知りたい。

応答：田中康政

舌下神経前位核の尾側端レベルでは，Mesulam \& Kaliaの分類で内側亜核の背側部に, area postvema の尾側付近のレベルでは，介在亜核に強く標識が認め られた。しかし孤束核への投射に関しては迷走神経上 神経節の関与もあり検討を要する。

155）ヒ卜胎児披裂部粘膜上皮の電顕的研究 酒井 昇, 末永 通, 田中克彦, 寺山吉彦 (北大耳鼻科)
ヒト胎児喉頭披裂部粘膜上皮の観察は，これまでい くつかの報告がみられるが，いずれも光顕レベルのも のである。今回われわれは, 走査型および透過型電顕 により, 胎生 $7 \cdot 8 \cdot 9 \cdot 12 \cdot 14 \cdot 16 \cdot 18$ 週（各 1 例） のヒト胎児披裂部粘膜上皮 (喉頭内側面のほぼ中央部) を観察し，若干の知見を得たので報告した。

結果：上皮層は胎生 7 週で $2 \sim 3$ 層の立方状細胞よ り成り，この時期で既に基底膜が明瞭に形成されてい た。その後上皮層の細胞は短円柱状となり, 胎生 9 週 以後は多列円柱上皮に移行していた。線毛細胞は胎生 8 週で，ごく一部にみられるのみであるが，以後胎生 18週まで漸次増加を示した。胎生 8,9 週の早期では, 短い線毛を有する細胞や，無線毛細胞の一部に数個の 中心子が細胞質内にみられるものがあり, 線毛の発生 過程を示すものと思われた。Primary cilium を有する 細胞は,グリコーゲン顆粒を大量に含む未熟な細胞と して胎生 7,8 週に出現するが, 胎生 9 週以後は認め られなくなった。無線毛細胞は胎生の早期で上皮の大 部分を占め, 大量のグリコーゲン顆粒を含んでいた。 胎齢が進むとともに無線毛細胞の数は減少するが，細 胞内小器官が漸増し, 胎生 16 週以後はグリコーゲン顆 粒は認められなくなった。

考按：今回の観察では primary cilia は従来いわれ ているように線毛細胞の出現に先立って一時的にみら れるものであることが確認された。線毛細胞の初発に ついては，これまで光顕的に胎生 11 週とされている が，われわれの観察からは胎生 8 週の早期であること がわかつた。グリコーゲン顆粒の意義については，細 胞の分化と比例して減少していることから，細胞の分 化に必要なエネルギー源ではないかと推測された。

156）輪状甲状筋の形態学的研究一第 2 報一 石井豊太, 原田宏一, 古川浩三, 八尾和雄 高橋広臣，設楽哲也（北里大耳鼻科） 新美誠司（東大音声研）

目的：前回の本学会で輪状甲状筋の直走筋，斜筋に ついて, 筋膜中央における断面積, 筋線維数の年歯に よる変化について報告した。今回は，同筋において抄 録に示した方法で，筋線維の型分類，筋線維径の計測 を定量的に行い，年齢による変化について検討した。

対象：男性28例，女性30例の計58例につき標本を作 成した。男性 20 歳以下は 7 例, 女性 20 歳以下は 5 例で ある。35歳以上 65 歳未満の男性は 10 例女性は 13 例, 65 歳以上は男性 8 例，女性 9 例である。

結果ならびに考察：筋線維の型分類において，赤筋 が全体の筋線維に対して，直走筋男性は37〜 54\%，女 性33～55\%，斜筋男性36～54\%，女性33～53\%，を占 めた。年齢および性別, 直走筋斜筋による筋線維の割 合のちがいはなかった。筋線維短径の計測では, 直走 筋, 斜筋とも, 自筋線維径が, 赤筋線維径よりも太く, $1 \%$ の危険率で統計学的に有意差を各年代で認めた。 男女における差はなかった。直走筋，斜筋とも，0 歳 から10歳代の間に筋線維径はほぼ直線的に増加し，成 人值に達し，65歳以上でわずかに減少したが，統計学 的には有意差は認められなかった。

筋線維数の検討では，直走筋・斜筋とも，自筋線維 数，赤筋線維数は，加齢にともない減少する傾向にあ 
日気食会報，37（2），1986

ったが，統計学的には明らかでなかった。

質問：久 育男 (京府医大耳鼻科)

Sudan Black B 染色のみで type 分類するのは危険 ではないか。

応答：石井豊太 (北里大耳鼻科)

今回は, 脂肪染色をする目的で Sudan-Black-B 染 色を行った。他の脂肪染色もする必要があると考えら れる。また Sudan-Black-B に染色された線維を赤筋 線維として報告した。

157）声帯上皮下結合織の走査電子顕微鏡による観

察 (その 2)

桑内隆郎，八井田昌志，森 茂樹，高須昭彦 岩田重信 (藤田学園耳鼻科)

我々は，声帯振動において重要視されている声帯上 皮下結合織の立体的構築を観察する目的で，走査電子 顕微鏡を用い上皮から筋層にかけて連続的に観察し た。

実験対象：喉頭癌，下咽頭癌患者よりの摘出喉頭を 使用した。(健側声带)

実験方法：仮声帯から声門下の高さまで，筋層を含 め切除し前固定後, 液化窒素を用いた凍結法にて割断 し固定した。

標本は直径 $35 \mathrm{~mm}$ の試料台を用い JSM-840にて 観察した。

実験結果：声帯下縁および声帯遊離縁部での結合織 は比較的太い膠原線維が密に上皮にそった形で走行 し，その内に弾性線維が存在していたのに対して，声 帯上縁部の結合織はほとんど膠原線維からなり，その 膠原線維は, 声帯下縁や声帯遊離縁部と比較すると細 く，また上皮層近くでは上皮にそった形で走行してい たが，筋層に近づくにつれ蜂巣状を呈していた。

筋層と結合織との結合は主として膠原原線維によっ てなされており，筋膜上を網状に走行する膠原原線維 が徐々に膠原線維に束ねられていくのが観察された。

これは声帯筋が発声時収縮したときに，粘膜波動を容

易にするためではないかと推測された。

質問：平野 実 (久大耳鼻科)

このことについては1975年に詳細な報告を行ってい

るが，何か新知見が得られたのか。

応答：桑内隆郎（藤田学園耳鼻科）

粘膜波動の起始部〜終了部までの経過に焦点をおい

て, 平野先生の層構造の研究を追試した。結果, 筋層 と結合織との接合部が粗であり, 声帯上縁部の結合織 は他の部位と比し粗であり蜂巣状を呈していた。

質問：永田博史 (千大耳鼻科)

筋膜に膠原原線維が結合するという所見は，全身の 他の筋肉には見られないのか。

応答：桑内隆郎

今回は，他の筋についての研究はしていない。

\section{第43群 画像診断}

座長 金子 敏郎 (千大耳鼻科)

158）頸部領域の超音波診断一 $T$ 臨床分類に即した 超音波解剖一

藤倉雄二，奥野哲治，志賀逸夫

(慶大放射線診断部)
村上 泰 (慶大耳鼻科)

頸部領域の超音波診断は，従来甲状腺・耳下腺を主 として行なわれてきたが，それらは腫瘤自体の存在・ 性状を述べるにとどまり周囲組織との関係にふれるこ とはあまりなかった。今回我々は，高分解能を有する 7. $5 \mathrm{MHz}$ リニア電子スキャナーを使用し, 頸部悪性腫 瘍のT臨床分類を目的とした超音波解剖を試みある程 度の結果を得た。対象は健常成人男子 2 名。

同定できた構造は甲状腺付近では気管，食道，総頸 動派, 内頸静脈, platysma, sternocleidomastoid, sternohyoid, sternothyroid, longus colli, Omohyoid, Prevertebral fascia 等で顎下腺付近では facial v., anterior belly of digastric, mylohyoid, 耳下腺付近で は parotid duct, retromandibular v., superficial temporal a., masseter 等である。

喉頭は前方より transverse scan で観察し，前連合

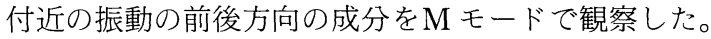
振動数は 50〜 $120 \mathrm{~Hz}$ の規則正しいもので周波数の最 も高い所が声帯遊離縁のレベルでこれより下方では周 波数は低くなるものと思われた。今後症例を重敉臨床 的応用につきさらに検討したい。

159）Reconstruction CT Imagingによる喉頭腫 瘍の画像診断

奥野哲治，志賀逸夫（慶大放射線診断部）

藤村昭子，村上 泰（慶大耳鼻科）

下咽頭・喉頭領域の病変の進展範囲の診断に CT は 有用であるが，軸位水平断面での画像表示に限られる ため, 垂直方向の病変の進展範囲の立体的把握に制限 がある。

今回, 安静呼吸時の軸位 CT 像から冠状断面, 矢状 断面, 披裂喉頭蓋ひだに沿った傍矢状断面における reconstruction CT imaging を試み，その診断的意義を 検討した。対象症例は, 喉頭癌 7 例, 下咽頭癌 6 例, 種々の要因による声帯麻痺 4 例, 喉頭アミロイドーシ ス 1 例, 下咽頭肉芽腫様炎症 1 例の計19例である。

結果) (1)声門部喉頭癌では, 声帯下面, 傍喉頭間隙, 前交連などの描出に優れる冠状断抽よび矢状断の reconstruction imaging が病変の垂直方向の把握に有用 であった。

(2)下咽頭抢よび声門上部の病変では，梨状陥凹壁， 披裂喉頭蓋ひだ，前喉頭間隙などの描出に優れる傍矢 状断の reconstruction imaging が病変の描出に有用で あった。

(3)声帯麻痺例では，麻痺側の披裂軟骨抢よび小角軟 骨の内前方への偏位, 披裂喉頭蓋ひだの肥厚, 麻痺側 梨状陥凹の拡大などの特徴所見の立体的把握が冠状断 および傍矢状断の reconstruction imagingにより容 易であった。

(4)基本的な $\mathrm{CT}$ 検查法である安静呼吸時の軸位 $\mathrm{CT}$ 像から容易に各断面の再構成画像を得ることができ, 1 例に要する検査時間も $10 \sim 15$ 分であり, 治療前検査 法として臨床的に有用であると考えられた。

160) Fuji Computed Radiography の喉頭疾患診 断への応用

態川孝三, 阿久津勉, 宮川晃一 (虎の門病院耳鼻科) 
山口宏也（東京専売病院耳鼻科）

I .はじめに : Fuji computed radiography（以下， FCR) は digital radiographyによる新しい画像診断 法の一つであり，すでに多数の領域で臨床応用がなさ れている。我々も FCR を耳鼻科疾患の診断に応用し, 特に軟部組織や上気道の撮影, 唾液腺造影などに適し ていることをすでに報告した。今回は喉頭の画像診断 について従来法によるX線画像との比軟を行い, その 有用性や今後の臨床応用の可能性について述べた。

II . FCR 装置と撮影方法：このシステムの基本的 な原理は次のようである。(1)撮影には従来の撮影装置 をそのまま使用する。(2)従来のX線フィルム一増感紙 の組合せに代えて鋭敏な検出系である揮尽性螢光体の イメージングプレートを使用する。(3)プレートを画像 読み取り機にかけて信号をディジタル化し, コンピュ 一夕を用いて種々の画像処理を行い，目的に合った最 も見やすい画像を作り出す。また従来法の $1 / 3 \sim 1 / 10$ と いう低線量で撮影が可能という利点も有する。撮影は 喉頭の単純撮影および前額断層撮影 (撮影間隔 $5 \mathrm{~mm}$ ) を従来法と FCR 法で行った。

III. 結果：単純撮影の FCR 画像では，喉頭を含め た上気道のコントラストがより明瞭に描出された。特 に側面撮影に診断価値が認められた。断層撮影の FCR 画像では, 喉頭内の各構造が従来法に比べてきわめて 明瞭に描出された。具体的には，(1)声帯，仮声帯の腫 脹の程度, (2)喉頭室, 声門下腔の状態, (3)声帯のレべ ル差，声帯の萎縮の程度，などについて従来法より確 実な情報が得られ，治療方針の決定および治療効果の 判定上, 有用であった。以上から FCR を喉頭の画像診 断に応用した場合, 診断能が高まると思われた。

また, 新しい応用法として, 液状シリコン注入術後 のシリコン塊を FCR 断層撮影で描出する試みと, エ ネルギーサブトラクション法によって骨陰影を消去す る喉頭の単純撮影法についても言及した。

\section{1）FCRによる小肾気道画像}

藤原久郎, 松村高洋 (長大耳鼻科)

小児気道系の検索には小児であるが故に，非侵襲的 検索法が望ましく,簡便な X線検査が第一選択である。 一般的には側方向鼻咽頭撮影法, 高圧撮影法が推奨さ れているが，目的とする部位の条件設定が難しく，十 分な情報を得るのに苦労しているのが現実であろう。 最近, 種々の digital radiography が出現してきてい る。これらの特徵は $\mathrm{A} / \mathrm{D}$ 変換した digital 情報をコン ピューターで処理する際に画像処理ができる所にあ る。今回, 我々は小児気道症例に FCR (Fuji computed radiography) による経過観察を経験した。

(症例) 4 歳, 女児。心奇形手術時, 術插管が原因と 考えられる subglottic stenosisである。T-tube を入 れ，3力月目に試験抜管してみたが，FCRでみると小 肉芽が気切上部に残っており再捙管している。 8 力月 目に $\mathrm{CO}_{2}$ laser laryngosurgery を行ない抜管。FCRで 肉芽消失を確認した。

(症例) 1 歳，女児。ピーナツの気管支異物症例。気 切を行って摘出したが， 2 週目，FCR を撮ってみると 気切部は楔状に切れ込みがみられ，その上下に肉芽形 成を認めた。1 カ月後には肉芽消夫を確認している。
FCR の第 1 の特徴はハロゲン化物の充填されたイ メージングプレートであり, 高感度, 広いラチチュー ドを持っている。画像処理ではコントラストのための 階調処理，鮮鋭度をコントロールするための周波数処 理がある。特に声門下気道軟組織をみる時には，階調 処理でコントラストをあげてやり, 周波数処理で frequency enhancement を行うと輪郭がみやすくなって くる。FCRを利用すれば目的とする所を画像処理によ り見やすくすることが可能で，小児気道系の診断には 有効であった。

\section{第44群 気管・気管支一基礎（1）}

座長 斎藤 久樹 (弘大耳鼻科)

162）気管切開による生理学的呼吸死腔の変化 柴田伊十児, 宮宗 影, 宇野 功, 高橋宏明 (阪医大耳鼻科)

気管切開による解剖学的死腔の減少は自明のことで あるが，生理学的死腔の変化についての検討はあまり 行われていない。そこで我々は, Bohrの死腔換気率式 を使用し，気管口呼吸と口呼吸の生理学的死腔を求め た。同時に，他の呼吸パラメー夕 (呼吸数, 一回換気 量, 呼吸時間, 呼吸抵抗, closing volume など）も測 定し呼吸様式の変化を調べた。

対象は肺疾患のない成人で気管切開を受けた者，お よび T-tube 插入者とした。

方法は熱線流量計，三方弁，ダグラスバッグを組み 合わせ, 被検者に 3 分間の安静呼吸を行わせ呼気を集 め, 呼気ガス分析器で $\mathrm{CO}_{2}$ 濃度を測定した。動脈血は 橈骨動脈の留置針により採取し, 血液ガス分析器にて, $\mathrm{PaCO}_{2}$ を求めた。これらの值を Bohrの式に代入し生 理学的死腔の值を求めた。

以上の操作を気管口呼吸と口呼吸とで行い経時的変 化をも観察した。

結果；1）気管口呼吸は口呼吸に比べ VD/VT は明 きらかに低下する。2）VD/VT は気管口呼吸への変更 後, 口呼吸への変更後, 変動する。3）気管口呼吸は口 呼吸に比べ呼吸抵抗は約半分で, 吸気時間が短く, closing volumeの増大傾向がある。

以上の結果の説明として, 気管口呼吸の場合，1）気 管口での狭窄により乱流が生じ吸気が末梢肺胞に到達 しにくくなる，2）換気血流比が変動し，肺胞死腔が 増加する,3）呼吸抵抗が急激に低下するため呼吸調節 が乱れる，などの機序が予測された。

質問：臼井信郎（東邦大大橋病院耳鼻科）

1) Closing volume 検查におけるI 相と II 相の変化 はどうだったか。

2) Closing volume \%の増大する理由をどう考える か。

\section{応答 : 宇野 功 (阪医大耳鼻科)}

1） I 相II相の変化（anatomical dead space）につ いては計測していない。

2) Closing volumeの増加の原因は不明。多分 small airway closure によるものと考える。

質問：岡田泰昌（慶大内科）

(1)生理学的死腔の変動機序として, 肺内ガス交換障 害の程度の変化が考えられるが, $\mathrm{AaDo}_{2}$ の変化はどう 
か。

(2)吸入気の温度・湿度の影響はどうか。

(3)肺内血流分布の変動はどうか。

応答：柴田伊十児

(1) $\mathrm{AaDO}_{2}$ について計測していないが多分増加して いるであろう。

(2)吸入気の加湿加温は，1例に行ってみたがあまり 変化はなかった。

(3)血流分布については, R I シンチ等で調べてみた いと思っている。

\section{3）気管支細気管支炎例の換気・血流比不均等分布} の解析

岡田泰昌，山沢文裕，河合 章，川城丈夫 横山哲朗（慶大内科）

目的：気管支細気管支炎例における肺内換気・血流 比 $\left(\dot{V}_{\mathrm{A}} / \dot{\mathrm{Q}}\right)$ 不均等分布について, その様相ならびに病 態生理学的意義の検討を目的とした。

対象：気管支細気管支炎例11症例を対象とした。対 象はいずれも病理組織検査にて比較的高度の末梢気道 病変が認められた症例である。これらの対象の中枢気 道病変の程度は様々であり, いわゆる細気管支炎例お よび気管支細気管支炎例を含んでいたが, 本研究では, これらを一括して気管支細気管支炎例として扱った。

方法：Wagner らの方法に従い，6種不活性ガスの 同時洗い出しを施行し, 対数 $\dot{V}_{\mathrm{A}} / \dot{\mathrm{Q}}$ の軸上の血流分 布, 換気分布を求めた。 $\dot{V}_{\mathrm{A}} / \mathrm{Q} 0.005$ 以下の血流は肺内 シャントとし， $\dot{V}_{\mathrm{A}} / \dot{\mathrm{Q}} 100.0$ 以上の換気は死腔換気と して扱った。

成績：11例中10例において多峰性の血流分布，換気 分布を有する高度の $\dot{\mathrm{V}}_{\mathrm{A}} / \dot{\mathrm{Q}}$ の不均等分布が観察され た。 1 例は 1 峰性の比較的幅の狭い血流分布, 換気分 布を有していた。肺内シャントは平均 $0.6 \%$, 最高 2.8 \%であった。

考察：慶応義塾大学病院肺機能室での正常棄却限界 により判定した 1 秒率が正常であった 4 例と, 異常で あった 7 例について, 低 $\dot{\mathrm{V}}_{\mathrm{A}} / \dot{\mathrm{Q}}$ 領域における血流分布 の様相を比較したが, 両群間に差を認めなかった。こ の観察結果は, 低 $\dot{V}_{\mathrm{A}} / \dot{\mathrm{Q}}$ 領域の血流量増加機序には, 中枢気道病変よりもむしろ末梢気道病変が関与してい ることを間接的ながらも示唆するものと思われた。肺 循環障害に伴う肺内血流分布障害が, $\dot{\mathrm{V}}_{\mathrm{A}} / \dot{\mathrm{Q}}$ 不均等分 布に及ぼす影響を検討した。肺血管抵抗と低 $\dot{V}_{\mathrm{A}} / \dot{\mathrm{Q}}$ 領 域の血流分布の様相とは, 対応関係を示さなかった。 しかし肺血管抵抗が, 異常高值を呈した 7 例において, 高 $\dot{V}_{\mathrm{A}} / \dot{\mathrm{Q}}$ 領域の換気量は，いずれも高值を示した。こ の観察結果は, 高 $\dot{V}_{\mathrm{A}} / \dot{\mathrm{Q}}$ 領域における換気量増加機序 に，肺循環障害に伴う肺内血流分布障害が関与してい ることを示唆するものと思われた。

164）ハウスダスト及びスギ花粉による気道過敏性 の局在

司 明理, 兒井信郎, 武安陽子, 堀井恵子 高木芳夫（東邦大大橋病院耳鼻科）

気道過敏性は過敏性を示す部位によって, 上気道の みに過敏性があるもの, 下気道のみに過敏性があるも の，上・下気道両方に過敏性があるものの3つに分け られる。我々は，気道過敏性の局在部位の差は何によ
るものかを調べる為に H. D. アレルギ一症例, スギ花 粉症症例を対象に気道誘発試験を行ない, 結果を部位 別に検討した。

H. D. アレルギー症例34例を H. D. 鼻アレルギー症 例14例, H. D. による下気道過敏症症例 8 例, 下気道症 状を伴う H. D. 鼻アレルギー症例12例の 3 群に分け, アストグラフでメサコリンによる気道誘発試験を行な ったところ，下気道症状を伴う H. D. 鼻アレルギー症 例が最も過敏性が高く, 次に H. D. による下気道過敏 症症例，H.D. 鼻アレルギ一症例の順であった。

スギ花粉症症例では鼻症状のみの症例14例, 下気道 症状を伴うスギ花粉症症例 8 例についてメサコリンに よる気道誘発試験を行なって検討した。下気道症状を 伴うスギ花粉症症例の方が, 鼻症状のみのスギ花粉症 症例よりも高い過敏性を示した。スギ花粉症症例につ いては発作期, 非発作期による過敏性の違いも観察し た。発作期の症例27例と非発作期の症例12例について スギディスクによる特異的鼻誘発試験を行ない, ライ ノグラフで呼吸抵抗を連続測定して過敏性を検討した ところ, 発作期には鼻過敏性は著明に克進し, 非発作 期にはほぼ正常レベルに低下することがわかった。

まとめ：

(1)アレルゲンの種類にかかわらず，気道過敏性は下 気道にあるものほど高くなる。

(2)周囲のアレルゲンの量によっても気道過敏性は変 化し，アレルゲンが無い時は過敏性は正常レベルにな り得る。

質問：山澤文裕（慶大内科）

気道過敏性テストを行う際に，気管支拡張剤や抗ア レルギー剤を投与したか。投与後で両者間に差はあっ たか。

応答：司 明理（東邦大大橋病院耳鼻科）

気道誘発試験を行なう際は気管拡張剂等の内服薬, 局所噴霧剂を全く投与しない状態で行なっている。ア トロベントを鼻より吸入させた後に行なったメサコり ンによる気道誘発試験では反応が抑制される場合がみ られる。

\section{第45群 気管・気管支一診断}

座長 立木 孝 (岩手医大耳鼻科)

165）びまん性汎細気管支炎の痰について 中村清一，木原令夫，長岡 滋 (都立広尾病院呼吸器科)

びまん性汎細気管支炎 (diffuse panbronchiolitis, 以下 DPB) は，呼吸細気管支を病変の主座とする予後 不良の慢性閉塞性肺疾患と考えられている。しかし， この疾患概念も含め, 病因, 治療等に関し, 未解決の 問題が数多く残されている。われわれは, DPB 患者の 痰の分析を通して本疾患の病態の特異性を探究するこ とを目的とした。

14例の DPB 患者の，35検体の粘液膿性痰と膿性痰， および22例の慢性気管支炎 (chronic bronchitis, 以下 CB) 患者の 22 例の粘液膿性痰についてその物理化学的 成分を比較した。分析項目は，以下の如くである。(1) $\mathrm{pH}$, (2)降伏值 (yield value), (3)电系性 (spinnability), (4)フコース濃度, (5)シアル酸濃度, (6) $\operatorname{IgA}$, (7) $\mathrm{IgG}, 8$ 
アルブミンである。

$\mathrm{DPB}$ は CB に比し, $\mathrm{pH}$ が高く降伏值が低く, 曳系 性が長い傾向がみられたが，いずれも有意差にはいた らなかった。生化学的成分では, フコース, シアル酸, アルブミンとも特記すべき傾向は認められなかった。 しかし, IgA は, DPBで有意に低く $(\mathrm{P}<0.01) \operatorname{IgG}$ で 高い $(\mathrm{P}<0.05)$ 傾向があった。

DPBを Stage 分類した。痰培養で haemophilus influenzae 陽性の Stage II : 16 検体と pseudomonas aeruginosae 陽性の Stage III：19 検体の痰の各々の パラメーターを比較してみたが，Stage 間には有意な 差は認めなかった。

更に，DPBの痰の線毛に及ぼす影響を検討した。 Rotating explant method による痰の上清の線毛運動 に及ぼす影響は，いずれもー $40 \%$ 以上の回転数の減少 を示した。またカエルロ蓋粘膜上での mucus transport rateで, 著明に輸送速度の遅かった痰のうち, DPB は72\%を占めていたが, 著明に速い痰には, DPB は 1 例も認められなかった。DPB は予後不良の慢性閉塞性 肺痰患であるが，その原因として痰中の IgA の低值に よる易感染性と痰の気道内クリアランスの低下が考元 られた。

質問：山澤文裕（慶大内科）

インフルエンザ桿菌と緑膿菌とで喀痰の性状に差は あるか。

応答：中村清一（都立広尾病院呼吸器科）

H. influ. と Ps. aergi, 陽性群では, 痰の性状に関し ては変化ないが, 線毛運動抑制に関しては, 菌そのも のによる違いが認められる。

追加 長岡 滋 (都立広尾病院呼吸器科)

Pseudomonas aeruginosae が多いと遊離型の elastase が増加して線毛を障害する可能性がある。

IgA は感染障害とともに痰の弾性の形成に関与して いる，これが低下することは，DPBが感染を誘発する ことと,痰が貯留することに関速していると思われる。

166）血痰症例の臨床的検討

前田秀彦，石塚洋一，長井大二，橋元裕明 (帝京大溝口病院耳鼻科)

当科に扔ける血痰症例について, 臨床的検討を加え たので， 3 症例とともに報告する。症例数は 34 例で, 当耳鼻咽喉科を初診したものは15例，他科よりの紹介 は19例であった。原因疾患の内訳は炎症性が22例で， 肺結核 3 例, 肺炎 3 例, 気管支炎 16 例。腫崵性は 10 例 で, 肺癌 7. 例, 気管支腺癌, 喉頭癌, 上咽頭癌が各々 1 例。その他肺囊胞 1 例, カフによる機械的压迫が 1 例であった。気管支ファイバースコープ下に擦過細胞 診をおこなった症例は31例で，クラス I・II は25例， クラスIV・Vの悪性は 5 例であった。また生検をおこ なった症例は23例で, 病理組織検査で悪性腫瘍と診断 されたものは 8 例, 炎症所見のみられたもの11例, 所 見の認められないものは 4 例であった。肺の悪性腫崵 については, 生検をおこなった 8 例はすべて病理組織 検査で確定診断がつき，擦過細胞診では 8 例のうち 5 例がクラスIV・Vを示し，診断上有意義な検査と考え られた。内視鏡下の細菌検査では結核菌や, 肺炎出血 の原因として多いクレブシェラ菌が検出され, 内視鏡
下の細菌検査も生検, 細胞診とともに有用な検査法と 思われた。

症例 1 は83歳で主訴は血痰。気管支鏡では右下葉肺 底区支内腔を充塞する表面平滑で発赤した腫場を認め た。病理診断は腺様囊胞癌であった。放射線 $2000 \mathrm{rad}$ 照射後, 内視鏡的電気焼灼により腫瘍を摘出した。症 例 2 は22歳男性で主訴は喀血。肺結核を疑い, 喀痰, 胃液の塗沫培養検査をくり返したが，菌は検出されな かった。気管支鏡下のブラッシング後の菌検で, ガフ キー 1 号が検出され，肺結核の確定診断がなされた。 症例 3 は61歳の男性で主訴は血痰。気管支粘膜に発赤 を認め，右上舌枝には膿計の貯留がみられた。急性気 管支炎による血痰と思われた。内視鏡下の擦過細胞診, 細菌検査，生検は確定診断を得る上で有用であり，血 痰症例については積極的な内視鏡検查が重要と思われ る。

\section{7）小葉中心性肺気腫症例における末梢細気管支 の定量的評価}

山澤文裕，小林弘祐，佐藤 勝，石坂彰敏 横山哲朗（慶大内科）

田中 満（慶大放射線診断部）

目的：選択的肺胞気管支造影像を用いて，小葉中心 性肺気腫症例における末梢細気管支を定量的に評価す ること。

対象：選択的肺胞気管支造影を施行し得た健常例 4 例，小葉中心性肺気腫症例 4 例を対象とした。

方法：被験者の右 B8a に直径 $2 \mathrm{~mm}$ のキーファー カテーテルを挿入した。水性ジオノジールを注入し末 梢肺領域を造影し， 3 ないし 4 倍拡大造影写真を撮影 した。解析に際しては, (1)肺胞像出現部位を始点とし, そこより中枢側の 3 分岐の細気管支径を直接測定する 方法(直接法)，(2) $2 \mathrm{~mm}$ 毎の同心円を描いた定規を用 い, 肺胞像出現部位を始点とし 5 つの同心円と交わる 細気管支径を測定する方法 (定規法)，(3)イレギュラリ ティ・インデックスの 3 法を用いた。

結果：末梢細気管支径の平均径は肺胞像出現部位よ り中枢側に向かい，(1)直接法：健常例で $0.33 ， 0.41$, $0.49 \mathrm{~mm}$, 肺気腫症例で $0.30,0.36,0.52 \mathrm{~mm}$ であり, 末梢より 2 分岐中枢側までの細気管支は肺気腫症例に おいて有意に狭小化していた。(2)定規法：健常例で 0 . $50,0.57,0.63,0.69,0.64 \mathrm{~mm}$, 肺気腫症例で 0.50 , $0.47,0.46,0.54,0.59 \mathrm{~mm}$ であり,末梢より中枢側 の 4.0/3.5 8.0/3. $5 \mathrm{~mm}$ の範囲において肺気腫症例 では有意に狭小化していた。(3)イレギュラリティ・イ ンデックスは健常例で $87.2 \%$, 肺気腫症例で $89.3 \%$ で有意差を認めなかった。

考按ならびに結語：(1)小葉中心性肺気腫症例におい ては健常例に比し未梢細気管支径の狭小化が 2 種の方 法で認められた。(2)イレギュラリティ・インデックス に有意差は認められなかった。

168）中高年者の副鼻腔気管支炎

粟田口省吾（公立学校共済組合東北中央病院 耳鼻科)

中高年者 8 例（男女各 4 例，43 73歳）の副鼻腔気 管支炎について述べた。 8 例の既往歴をみれば，9歳 時からうつ病になった 67 歳女子の例以外は,いずれも, 
小児〜青年期に，鼻副鼻腔の炎症あるいは肺炎，ぜん そく, 肺浸潤などと診断された呼吸器疾患に罹患した ことがあった。主訴は鼻閉，鼻汁過多，せき，たんが 多いことで 2 例はときどき呼吸因難があった。 8 例全 例両側慢性副鼻腔炎で，既に根治手術を受けた 3 例以 外のX線写真では両側上顎洞のびまん性陰影がみられ た。鼻茸は 7 例にみられ, いずれも両側鼻腔にみられ, 殆ど鼻腔を閉鎖している例もあった。両側副鼻腔炎根 治手術（十鼻茸摘出術）ないしは鼻茸摘出術を行った これら 8 例は, 術後 $4 \sim 1$ 年の観察では, 鼻茸の再発 をみた例はなかった。ただし，1例（73歳男）は脳軟 化で，他の 1 例（43歳男）は急性肺炎で，いずれも術 後 2 年で死亡した。 8 例の胸部X線像は両側あるいは 1 側下肺野の異常（雲状）陰影がみられ，慢性気管支 炎ないしは気管支拡張症と診断した。肺換気機能は 2 例をのぞいて, 拘束性, 呼出性あるいは混合性の障害 がみられた。これら肺換気機能障害は, 鼻腔通気が手 術により正常となっても，改善されなかった。

まとめとして，中高年の副鼻腔気管支炎患者は，肺 換気機能が障害されているものが多く，鼻閉や鼻漏過 多のため, 肺炎にかかりやすくなるので, 鼻副鼻腔の 慢性炎症を根治させ, 肺炎の併発を防ぐことが必要で ある。なお, 中高年者の鼻茸の再発は比較的すくない。

質問：岡田泰昌（慶大内科）

臨床上, 対象例の鼻症状と気道症状はどちらが先に 出現したか。

応答：粟田口省吾（公立学校共済組合東北中央病院 耳鼻科)

鼻腔と副鼻腔と気管支疾患のどちらが先に発生した か，正しく決定することは困難である。

\section{第46群 気管・気管支一基礎（2）}

座長 水越 治 (京府医大耳鼻科)

169）器官培養法による気管粘膜の細胞分化に関す る研究 (第 3 報)一特に Alkaline Phosphatase 活 性を用いた研究 鈴木栄一, 弓削庫太, 中村兼一, 村上光伸 柏戸 泉，増野光子 (日医大耳鼻科)

今回，我々は培養気管上皮細胞の発育・分代を alkaline phosphatase (Alp) を marker として, 電顕組織 化学的に調べた。

実験結果：妊娠ウイスター系ラットより胎仔を取り 出し, 顕微鏡下に無菌的に気管を摘出。寒天培地に封 入し, $\mathrm{CO}_{2}$ lncubatorにて培養, 経日的に取り出しパラ ホルムアルデヒド固定後, 小川一馬屋原法により Alp 活性を検出し，電子顕微鏡的に観察した。

実験結果：胎生16日群では，上皮は単層に配列し， 線毛も分泌顆粒も認めなかった。Alp 活性は上皮の遊 離表面, 核膜及び核内と基底膜に強く見られた。胎生 16日の 4 日培養群では線毛細胞と分泌細胞が出現して いた。Alp 活性は, 細胞遊離表面にのみ強く認められ た。胎生17日群では, 線毛細胞・分泌細胞が見られな かった。Alp 活性は, 胎生16日群と,ほぼ同様であった。 胎生17日 3 日培養群では, 線毛細胞, 分泌細胞がはつ きり認められた。Alp 活性は幼若な線毛細胞では線毛 に活性が見られ，分化の進んだ線毛細胞には活性が弱
かった。しかし分泌細胞では遊離表面に活性が強かっ た。

考察：Alp は生理的意義は確定していないが，蛋白 合成すなわち分泌・吸収及び細胞の発育・分化の指標 となると言われている。今回の気管の培養実験におい て気管上皮内の本酵素の局在を調べたところ, 発育・ 分化にともない, その活性局在に変化が生ずることが わかった。このように気管上皮においても，細胞の発 育・分化に Alpが重要な役割を担っていることが考え られる。

質問：田中克彦（北大耳鼻科）

アルカリホスファターゼ染色の機能的意味付けは。

応答：鈴木栄一（日医大耳鼻科）

生体内に打ける，種々の影響を取り除くために，気 管粘膜の培養を行った。その成長の Markerとして Alpを用いた。

質問：中井義明 (阪市大耳鼻科)

発生過程中の線毛に Alk. P-ase が存在するとのこ とであるが, 成熟気管での再生線毛でも同様な所見で あるか。

応答：鈴木栄一

今回は, 主として胎仔の気管粘膜の Alpで研究し た。成熟ラットはしていない。

170）ヒト気管腺終末部内に見出された Oncocyte 様細胞の電子顕微鏡的観察 鎌田英男，亀井民雄（群大耳鼻科） 平 一男, 柴崎 晋 (群大第一解剖)

Oncocyte (Hamperl, 1931) は，光顕的に細胞質内 に好酸性顆粒が充満し，核がやや濃染する腫大した細 胞で oncocytoma の構成細胞として知られる。電影的 には極めて系粒体に富む細胞とされ，ヒトでは正常耳 下腺・気管支腺での報告があるが，気管腺については 中山（1976），柴崎・中山（1979）の報告の他に電顕的 研究は見当たらない。我々は，気管切開時または喉頭 全摘出時に採取した正常と思われるヒト気管腺終末部 に oncocyte 様細胞を見出し, その由来, 内部構造につ いて若干の知見を得たので報告した。材料は Karnovsky 液にて固定し, 定法に従い脱水, 包埋, 超薄切片を 作成し電子染色を施し観察した。

Oncocyte 様細胞内には多数の特異な形態を示す糸 粒体と漿液性と思われる分泌顆粒が観察されたが，そ れらの数は細胞により異なる。このような糸粒体の少 ない細胞にはゴルジ装置・粗面小胞体等の細胞内小器 官及び“漿液性”分泌顆粒が多く認められたが，系粒体 の多い細胞には小器官や分泌顆粒は少なかった。細胞 が糸粒体で充満する oncocyte の細胞質内には特異な 糸粒体の他には細胞内小器官はほとんど認められな い。Oncocyte 様細胞は典型的な漿液性腺細胞や oncocyteの間に混じて，単独または少数個の集団としてみ られるほか，時には腺房を囲んで全ての細胞が oncocyte 様細胞で占められていることがある。このことは oncocyte 様細胞が漿液性腺細胞と密接に関連するこ とを示唆する所見と考える。特異な形態を示す系粒体 の多くは膨大し，低電子密度の基質をもち，クリス夕 の分布は不均等であり，集合し束状または弓状の集団 をなすことがあり，クリスタにそしい糸粒体基質の小 
野がみられることがある。また基質内に結晶様体ある いは高電子密度の球状封入体をもつものも認められ た。

また増殖が盛んな卵細胞・腫瘍細胞等に認められる Annulate lamellae 様構造がこの細胞内にも認められ ることが注目される。

\section{1）H. influenzae による粘液線毛輸送系への影響 - Mucociliary Transport Force $の$ 測定によ $\eta-$}

山木健市, 野田康信, 高木健三, 佐竹辰夫 (名大第二内科)

粘液線毛輸送系 (MCT 系) は, 気道において, 有害 吸入物，ウイルスおよび病原性細菌を末梢気道から排 除し生体の有力な防御機構となっている。 $\mathrm{MCT}$ 系の 機能低下は，感染の誘因となるほか，炎症を拡大する 誘因となる。H. influenzae は呼吸器感染症の起炎菌と して高頻度に検出され, 慢性呼吸器疾患の進展に重要 な役割りを果していると考えられている。今回は，H． influenzae が産生する物質が MCT 系機能に及ぼす影 響を検討した。

(方法) MCT 系機能の測定：第35回・第36回の本学 会学術講演会に扔いても発表した，mucociliary transport force(MCTF) を測定する方法を用いた。Organ bathに粘膜を上に向けカエル口蓋粘膜をピン固定し た。ガラス製 boatを粘膜に乗せ, boatを粘膜が動かそ うとする力を張力として transducer で測定し MCTF とした。Organ bath 中の溶液を替えることにより, 薬 剤を簡単に作用できる。

H. influenzae の処置：H. influenzae は ATCC9334 株を用いた。Bacto enrichmentを加えた trypticase soy broth 液体培養に培養後，ホルマリン処理後に培 養上清から硫安法により蛋白質を含んだ Fraction A を沈澱分離した。残りの分画を Frartion B とした。各 Fraction は透析後, 凍結乾燥した。

(結果) Fraction A は， $0.1 \mathrm{mg} / \mathrm{ml}$ で10分後に，2.6 \%，20分後に $5.5 \%$ MCTF を低下させた。 $1 \mathrm{mg} / \mathrm{ml}$ それぞれ7.2\%, $12.7 \%, 10 \mathrm{mg} / \mathrm{ml} て ゙ 5.8 \%, 10.7 \%$ 低 下させた。一方, Fraction B は, $0.1 \mathrm{mg} / \mathrm{ml}, 10 \mathrm{mg} / \mathrm{ml}$ では MCTF は変化しなかったが, $1 \mathrm{mg} / \mathrm{ml}$ で, 10 分後 に2.6\%，20分後に $12.3 \%$ のCTF を増加させた。

(まとめ) H. influenzae の産生物質，蛋白質を主成 分とする Fraction A は MCT 系機能を低下させ，一 方, endotoxin を含む Fraction B は MCT 系機能を増 加させた。H. influenzae の感染は，MCT 系機能を変 化させることが判明した。

質問：坂本邦彦（鹿大耳鼻科）

H. influenzae の線毛運動抑制の機序は，膜障害であ ろうと考えられるが，どうか。

応答：山木健市（名大第二内科）

Endotoxin を長時間作用させて MCTF を測定した ことはない。Endotoxin は細胞膜の障害を最終的には 起こすと思う。

質問：野々村直文（新大耳鼻科）

(1)Fraction A，Bについてリムルステストを行って いるか。

(2)蛋白質は, 菌より分泌されたものか, それとも cell fragmentsによるものか。

応答：山木健市

(1) Fraction A，Bにリムルステストは行っていな い。

(2)Fraction 中の蛋白は, cell fragment $の$ 可能性も ある。純粋に産生された蛋白だけとは限らないと思う。

172）気道粘液線毛機能と干渉低周波

坂本邦彦，清田隆二，伊東一則，松崎 勉

内溒明裕, 上野員義, 大山 勝(鹿大耳鼻科)

川合 满, 加藤元一（京大結研内科）

中神和清, 周東 寛 (昭大藤が丘病院内科)

溝井一敏（伊勢慶應病院ME部門）

慢性呼吸器疾患患者の喀痰喀出困難に対する理学的 排疾法の 1 つとして川合らが開発した干渉低周波療法 の作用機序に関して 5 項目の基礎的な検討を行なっ た。

（研究項目および方法） 1，モルモットを用い，干 渉低周波（以下，ILF とする）刺激前後の気管粘膜組 織血流量を継時的に測定した。2, モルモットを用い， ILF 刺激に対する線毛運動の変化を in vivo 光電気的 解析法により検討した。3, モルモットを用い, ILF 刺 激後の気道粘液量を肉眼的に検討した。刺激部位と刺 激条件も変化させて適正な刺激部位と刺激条件を求め た。走査電顕により, 分泌状態を観察し, アトロピン 前投薬による分泌変化も検討した。4, ILF 刺激のモ ルモット回腸平滑筋に及ぼす影響を検討した。 5 ，成 犬を用い, 気管の粘液線毛輸送能と ILF 刺激の関係を 映画撮影により in vivo で検討した。

(成績) 1, ILF 刺激により, 組織血流増加が示唆 される成績が得られたが, 最終的な結論は今後の研究 にまたねばならない。2，繊毛運動に対して ILF の影 響はみられなかった。 3 , ILF 刺激により気道分泌は 著しく六進した。SEM 像からは, 腺から分泌されてい ることがわかった。刺激部位は両側上腕か気管を直接 刺激した場合が最も有効で，しかも $99 \mathrm{~Hz}$ の刺激条件 が最も有効であった。アトロピン前投薬により, ILF 刺 激による分泌交進は抑制された。 $4,4000 \mathrm{~Hz}$ の搬送電 流でも, ILF 刺激でも，モルモット回腸の平滑筋の収 縮や弛緩は認められなかった。 5 , 映画撮影では輸送 能の増加が示唆された。

(考按) ILF 刺激による分泌元進作用には自律神経 が関与していると考えられるが，血圧，脈拍数，心電 図に変化が認められないなどの矛盾点もあり，今後の 詳細な検討が待たれる。また，頭頸部領域へ応用する ことも可能である。

\section{第47群 気管・気管支一基礎（3） \\ 座長 中井 義明 (阪市大耳鼻科) \\ 173）胃液注入による気管上皮の変化 二宮優子 (吉田総合病院耳鼻科) 大屋耕子，工田昌也，原田康夫 (広大耳鼻科)}

胃液の気道内誤嚥によってひきおこされる肺炎は Mendelson's syndrome と呼ばれ全身麻酔時や脳外 傷, ショックなどの意識障害における重大な合併症の 一つであるが，その際の気道の微細形態に関しては未 
だ不明な点も少なくない。今回，我々は Mendelson's syndromeの病態を明らかにするため，家鬼気管に少 量胃液及び塩酸を注入しそれによる気管粘膜上皮の形 態的変化を, 田中らの $\mathrm{O}-\mathrm{D}-\mathrm{O}$ 法を用いて走查電顕, な らびに透過電顕を用いて観察した。

$<$ 方法 $>$ 体重 $2 \mathrm{~kg}$ 前後の白色家鬼の気管に，上卜胃 液 $(\mathrm{pH} 1.56) 0.2 \mathrm{ml}$, 塩酸 ( $\mathrm{pH} \mathrm{1.56)} 0.2 \mathrm{ml}$ を注入。 注入後 $0,17,44,72,90$ 時間後の気管を摘出, O-D $-O$ 法に従い走査電顕用試料を作製, 一部は透過電顕用 試料とした。

＜結果＞今回 O-D-O 法により試料作製を行なった 結果, 気管粘膜上皮細胞の微細立体構造が観察可能で あった。胃液，塩酸注入直後では気管粘膜上皮には変 化は認められなかった。注入後17時間では，フィブリ ンが大量に析出している部分がみられ, 線毛光端部の ポリープ状膨化, 複合線毛, 杯細胞の膨化などがみら れた。さらに細胞内部もミトコンドリアの膨化，空胞 変性などが認められた。注入 44 時間後で胃液, 塩酸と もに障害は最も高度となり線毛がほとんど脱落してい る部分や, 線毛細胞, 杯細胞が脱落し基底細胞が露出 したり, 基底膜の露出している部分もあった。以上の 変化は末梢側ほど強く，部位差が認められた。注入 90 時間後では，個体差，部位差を認めるもののほぼ正常 に回復していた。

〈考察およびまとめ>気管上皮は，少量胃液誤嬹に より，早い時期に障害を受け，このような変化が上方 への粘液輸送障害を引き抗こし, 気管終末部や, 肺胞 部で重篤な変化をおこすことが推察された。

質問：中井義明（阪市大耳鼻科）

1) 肺の変化は如何か。

2) 胃液の組成について。

応答：二宮優子（吉田総合病院耳鼻科）

1) 今回の注入量では，気管支も気管と同様の変化 を示したが, 肺胞のレベルでは，障害は軽度であった。

2 ）今回使用した胃液は，食物残涬等不純物を除い たものを使用した。

174）イソプロピルアルコールの気管粘膜障害に関

\section{する実験的研究}

大橋淑宏，中井義明，池岡博之，古下博之

江崎裕介(阪市大耳鼻科)

堀口俊一，寺本敬子，中世古博之 (阪市大衛生学)

〔目的〕イソプロピルアルコール (IPA) 消消毒剤な どに使用される有機溶剤で, IPAを取り扱う作業者に 喉頭癌や上顎癌の発生頻度の高いことが知られてい る。そこで，IPA 曝露の気管粘膜に及ぼす影響を検討 した。

【研究材料および方法] 体重 $250 \mathrm{~g}$ のモルモット48匹 に $400 \mathrm{ppm}$ (許容濃度) または $5500 \mathrm{pm} の$ IPA を24時 間連続曝露し，曝露終了直後より 2 週後まで気管粘膜 の病態を機能と形態の両面より経時的に観察した。 [成績]

1. 線毛運動数の観察： $400 \mathrm{ppm}$ 曝露群および 5500 ppm 曝露群の両者で線毛運動数の減少が曝露終了直 後には認められたが, $400 \mathrm{ppm}$ 曝露群では曝露 2 週後 には正常レベルまで回復することが観察された。一方，
$5500 \mathrm{ppm}$ 曝露群では曝露終了 2 週後でも線毛運動数 の低下が認められた。

2. 電子顕微鏡による観察：IPA 曝露後の気管粘膜 上皮では，複合線毛の形成，上皮細胞の空胞化，炎症 性細胞の上皮層内侵入, 細胞間隙の著明な拡大などの 像が観察された。 $400 \mathrm{ppm}$ 曝露群では曝露終了 2 週後 にはこれらの所見は消失することが観察されたが, $5500 \mathrm{ppm}$ 曝露群では 2 週後にも形態学的変化が認め られた。

〔まとめ]IPA は気管粘膜の線毛運動と上皮形態を 障害し, 著明な細胞間隙の拡大が特徵的であることが 認められた。また，その障害の修復には長期間を要す ることが示唆された。

質問：工田昌也（広島大耳鼻科）

イソプロピルアルコールの粒子系は。また鼻粘膜と 気管支粘膜の修復の早さは。

応答：大橋淑宏（阪市大耳鼻科）

曝露の種類, 濃度, また動物の種類によって差異が ある。

質問：田中克彦（北大耳鼻科）

細胞間隙が開大しているのは基底細胞層の障害が強 いということか。

応答：大橋淑宏

基底細胞に障害があるので，修復期にも影響が発現 するものと考える。

175）ウイルスによる気道感染症の実験的研究

本村昌一（函館中央病院耳鼻科）

田中克彦，福田 諭，末永 通(北大耳鼻科)

目的：ウイルスによる気道感染症の病態については すでに光顕および免疫螢光抗体法により多くの知見が 得られているが, 電顕による観察は多くない。今回我々 は，センダイウイルスによる実験的気道感染症の病態 を電顕的に観察したので報告した。

方法: 力価 $10^{6-2} \mathrm{EID} / \mathrm{ml}$ の名古屋株センダイウル ス $0.02 \mathrm{ml}$ を 4 週齢マウスに経鼻滴下接種し経時的に 気管，肺を採取した。3\%グルタールアルデヒド液， $1 \%$ オズミック酸液にて固定後通常の手順で透過型, 走查型電顕用試料を作った。センダイウィルス感染を 確認するためにウイルス接種後 2 日目に気管，肺を採 取し通常の間接法に従い免疫螢光抗体法のための試料 を作った。

結果：(1)免疫螢光抗体法によりウイルス接種後 2 日 目の気管上皮細胞に特異螢光を認めた。

(2)透過型電顕によりウイルス接種後 3 日目および 5 日目の線毛細胞の細胞質内にウイルス蛋白を認めた。 細胞表面にウイルス粒子はみられなかった。

(3)気道上皮の経時的変化は接種後 3 日目までは特に 変化がみられないが，5日目からは上皮細胞のミトコ ンドリアの膨化, 空胞変性, 細胞間隙の拡大, 線毛数 の減少, 線毛の bleb formation, 膠着, 萎縮がみられ, 8 日目では著明な上皮細胞の変性脱落, 一部に線毛の 再生がみられ，1 1 日目では気管上皮はほぼ正常に回 復したが，気管支上皮には変性像が残存していた。

考察：透過型電顕によるウイルス蛋白の確認は免疫 螢光抗体法における特異螢光の形態的裏付けである。 細胞表面にウイルス粒子がみられなかった理由は不明 
である。病変の経時的変化は従来の報告とほぼ一致し た。病変は気管より気管支へ進行するように思われ経 鼻滴下接種法と関連するものと考えられた。

質問：中井義明 (阪市大耳鼻科)

細菌感染に比しウイルスに特徵的な変化は何か。
応答：田中克彦（北大耳鼻科）

ウイルス病変の特徵は細胞病変が初期には殆どみら れず, かつ細胞体内にウイルス蛋白が増生している, 好中球浸潤を伴わないなどの点と思われる。 